\title{
Gravity and Magnetic Evidence of Lithology and Structure in the Gulf of Maine Region
}

GEOLOGIGAL SURVEY PROFESSIONAL PAPER 726-B

Prepared in cooperation with the National Oceanic and Atmospheric Administration

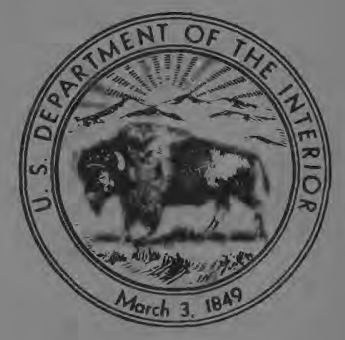





\section{Gravity and Magnetic Evidence of Lithology and Structure in the Gulf of Maine Region}

By M. F. KANE, M. J. YELLIN, K. G. BELL, and ISIDORE ZIETZ

GEOPHYSICAL FIELD INVESTIGATIONS

GEOLOGICAL SURVEY PROFESSIONAL PAPER 726-B

Prepared in cooperation with the National Oceanic and Atmospheric Administration

A study of regional gravity and aeromagnetic maps of the Gulf of Maine using anomaly-lithology correlations established in nearby land areas

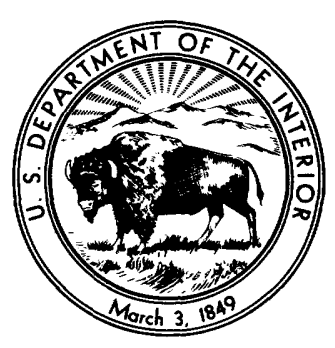




\section{UNITED STATES DEPARTMENT OF THE INTERIOR \\ ROGERS C. B. MORTON, Secretary}

\section{GEOLOGICAL SURVEY}

V. E. McKelvey, Director

Library of Congress catalog-eard No. $70-188161$

For sale by the Superintendent of Documents, U.S. Government Printing Office

Washington, D.C. 20402 - Price \$1.25 (paper cover)

Stock Number 2401-2078 


\section{CONTENTS}

Abstract

Introduction

Acknowledgments

Previous investigations

Geologic framework

Geophysical interpretation

Gravity and aeromagnetic surveys

Lithic units and anomalies

Quantitative analysis

Regional gravity

Local gravity anomalies

Land areas

Coastal areas
Page

B1

1

1

1

1

4

5

5

5

7

Geophysical interpretation-Continued

Page

Local gravity anomalies-Continued

Gulf of Maine region _. B8

Aeromagnetics _-_ 11

Regional magnetic field _._. 11

Land areas ____________ 11

Gulf of Maine region 13

Geologic implications of the gravity and magnetic anomalies

Structure _._- 17

Crustal structure of the Gulf of Maine

Summary _-_____- 20

References cited _- 20

\section{ILLUSTRATIONS}

Plate 1. Bouguer gravity and geologic map of the Gulf of Maine region

Page

2. Aeromagnetic and geologic map of the Gulf of Maine region

In pocket

In pocket

FIGURE 1. Regional geologic map of part of the northern Appalachian region

B2

2. Bathymetric and location map of the Gulf of Maine

3

3. Provisional lithologic map of the indurated bedrock of the Gulf of Maine

4. Crustal model showing regionalized Bouguer gravity field, maximum horizontal gravity gradients, and hypothetical density distribution of the Gulf of Maine-Maine region 



\title{
GEOPHYSICAL FIELD INVESTIGATIONS
}

\section{GRAVITY AND MAGNETIC EVIDENCE OF LITHOLOGY AND STRUCTURE IN THE GULF OF MAINE REGION}

\author{
By M. F. KANE, M. J. YelLiN, ${ }^{1}$ K. G. Bell, and IsiDore ZIETZ
}

\begin{abstract}
The aeromagnetic and gravity fields over the Gulf of Maine are characterized by well-defined regional zones and widespread intense anomalies. The dominant trend of the fields is northeast like that of the adjoining Appalachians. Most anomalies arise from igneous plutonic and volcanic sources, many of which are mafic in composition. Two adjoining parallel magnetic belts, one featureless and the other made up of intense anomalies, trend northeast through the gulf and extend to adjoining land areas of Maine and Massachusetts. The belt of intense anomalies defines a zone which is underlain in land areas, and presumably in the gulf region, by a high concentration of mafic rocks. It apparently marks the location of a major crustal fault zone. The central part of the gulf is underlain by indurated bedrock in which igneous plutons are abundant; gravity data indicate that moderate thicknesses of sedimentary rocks, possibly deposits of Carboniferous age, may also be present in this area. Correlations of areal geology with anomaly patterns and levels in land areas suggest that much of the crystalline bedrock underlying the gulf may be early Paleozoic or Precambrian in age. Discontinuities in regional anomaly patterns indicate the presence of major faults along the northwest and northeast margins of the gulf. Analysis of the regional gravity field shows that the crustal block underlying the gulf is distinguished from that of the surrounding land by high-density rock at relatively shallow crustal depths. The region is in near isostatic equilibrium, and at least part of the equilibrium is achieved by broad masses within the earth's uppermost crust.
\end{abstract}

\section{INTRODUCTION}

The Gulf of Maine, a broad shallow depression in the east margin of the North American Continent (fig. 1), is bordered landward on three sides by the Appalachians, and seaward by the shallow banks of the outer continental shelf. The bottom of the gulf is a complex of basins, swells, and ridges (fig. 2) which contrast with the smooth tablelike bathymetry of the bordering banks. The thicknesses and attitudes of the sediments that mantle the gulf bottom have been investigated extensively by continuous seismic profiling (Uchupi, 1966), but the lithology and structure of the underlying indurated bedrock are largely unknown. In this report mag-

\footnotetext{
'National Ocean Survey, National Oceanic and Atmospheric Administration, Groton, Conn.
}

netic and gravity surveys of the gulf region are analyzed in terms of structural trends, probable lithology of the indurated bedrock, and crustal structure.

The use of gravity and magnetic surveys to infer the geology of completely obscured bedrock involves considerable uncertainties, partly because of the inherent ambiguity of the geophysical methods and partly because of the manyfold correspondences between anomalies and rock types. Geophysical investigations of the bedrock in regions surrounding the Gulf of Maine are, however, comparatively advanced (for example, Garland, 1953; Griscom and Bromery, 1968; Kane and Bromery, 1968) and provide considerable data on empirical correlations between gross geologic units and their associated geophysical fields. The interpretation in this report makes use of a few well-established lithology-anomaly correspondences but relies to a great extent on the empirical correlations in the nearby land areas. This practice leads to a degree of uncertainty which is reasonably small for predictions of gross lithology but which may be fairly large for speculations about the structure and age of the bedrock. These factors require consideration in evaluating any particular conclusion of the report.

\section{ACKNOWLEDGMENTS}

We are indebted to John R. Kirby, whose knowledge of the aeromagnetic data was a major resource, and to Andrew Griscom for his counsel on the interpretation of the aeromagnetic maps. D. Duncan Arnold and David N. Packham generously provided able navigation and transportation to the islands off southern Maine in the summer of 1968.

This work stems in large part from a dissertation done with the encouragement and guidance of Professor Otto W. Nuttli of St. Louis University, St. Louis, Missouri (Kane, 1970).

\section{PREVIOUS INVESTIGATIONS}

In a study of the shallow stratified rocks underlying the Gulf of Maine, Uchupi (1966) synthesized the 


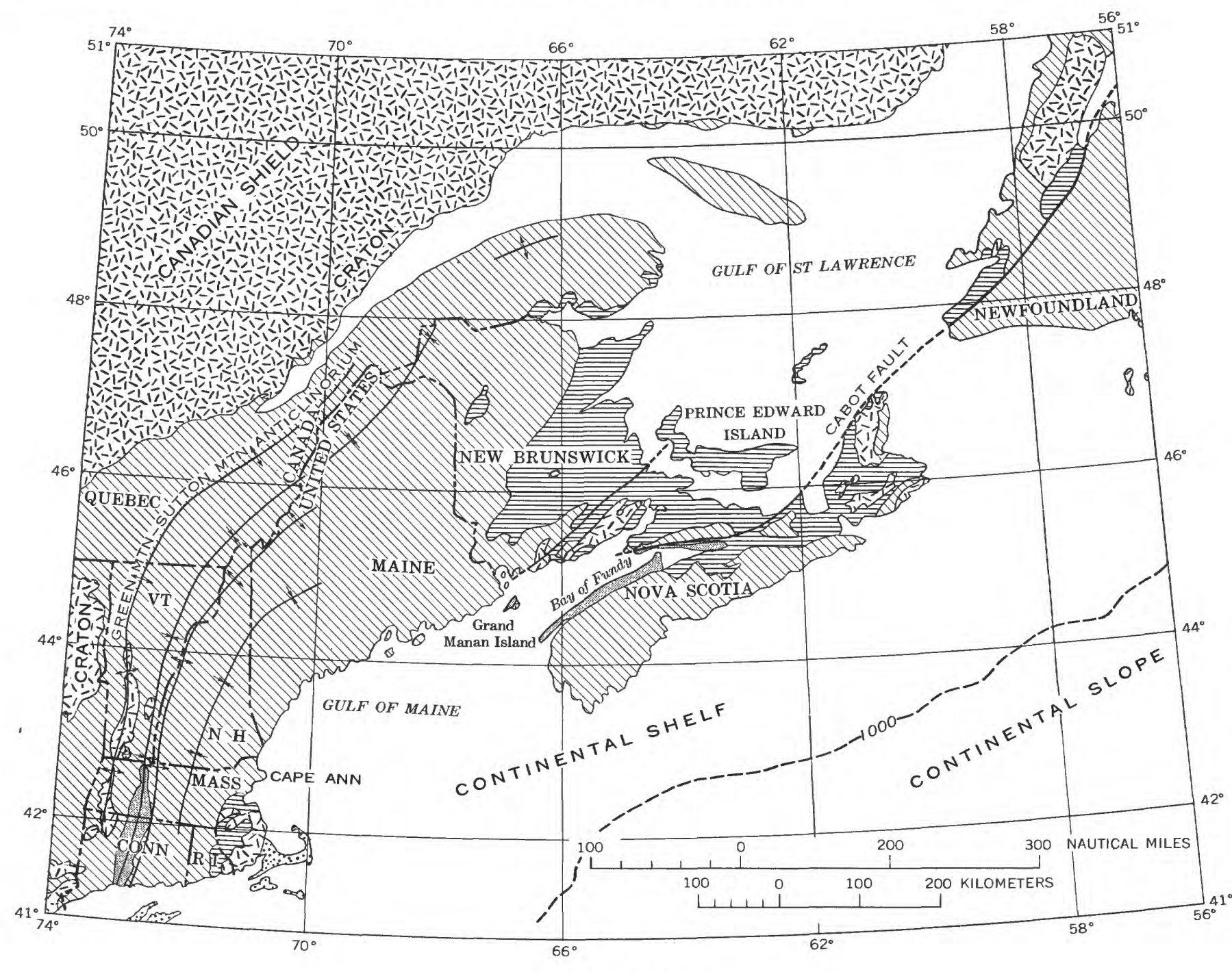

EXPLANATION

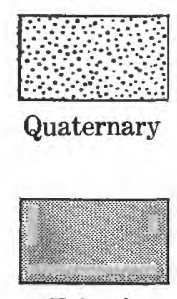

Triassic

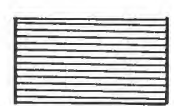

Carboniferous

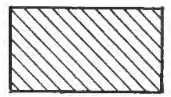

Devonian to Cambrian

FIGURE 1.-Regional geologic map of part of the northern Appalachian region. Geology modified mainly from King (1969); additions from White (1968); and generalized structure in Quebec, Maine, New Hampshire, and Vermont from Cady $(1960,1967)$, in Vermont from Doll,

findings of earlier investigations with his results and reported the following conclusions: Strata of Triassic age underlie a broad irregular zone which extends from the Bay of Fundy 120 kilometers southwest into the gulf. Strata of Cretaceous age
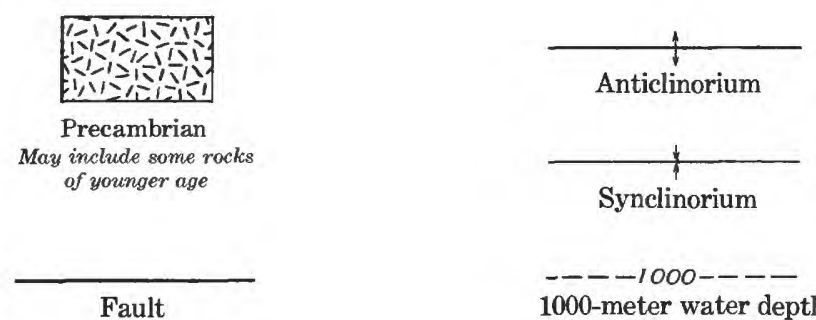

Cady, Thompson, and Billings (1961), in New Hampshire from Billings (1955), in Maine from Osberg, Moench, and Warner (1968), and in Connecticut from Dixon and Lundgren (1968).

are restricted to Georges Basin and Georges Bank (Emery and Uchupi, 1965), except possibly for some erosional remnants in Cape Cod Bay (Hoskins and Knott, 1961). Strata of Tertiary age underlie the area of Georges Bank and are present in a con- 


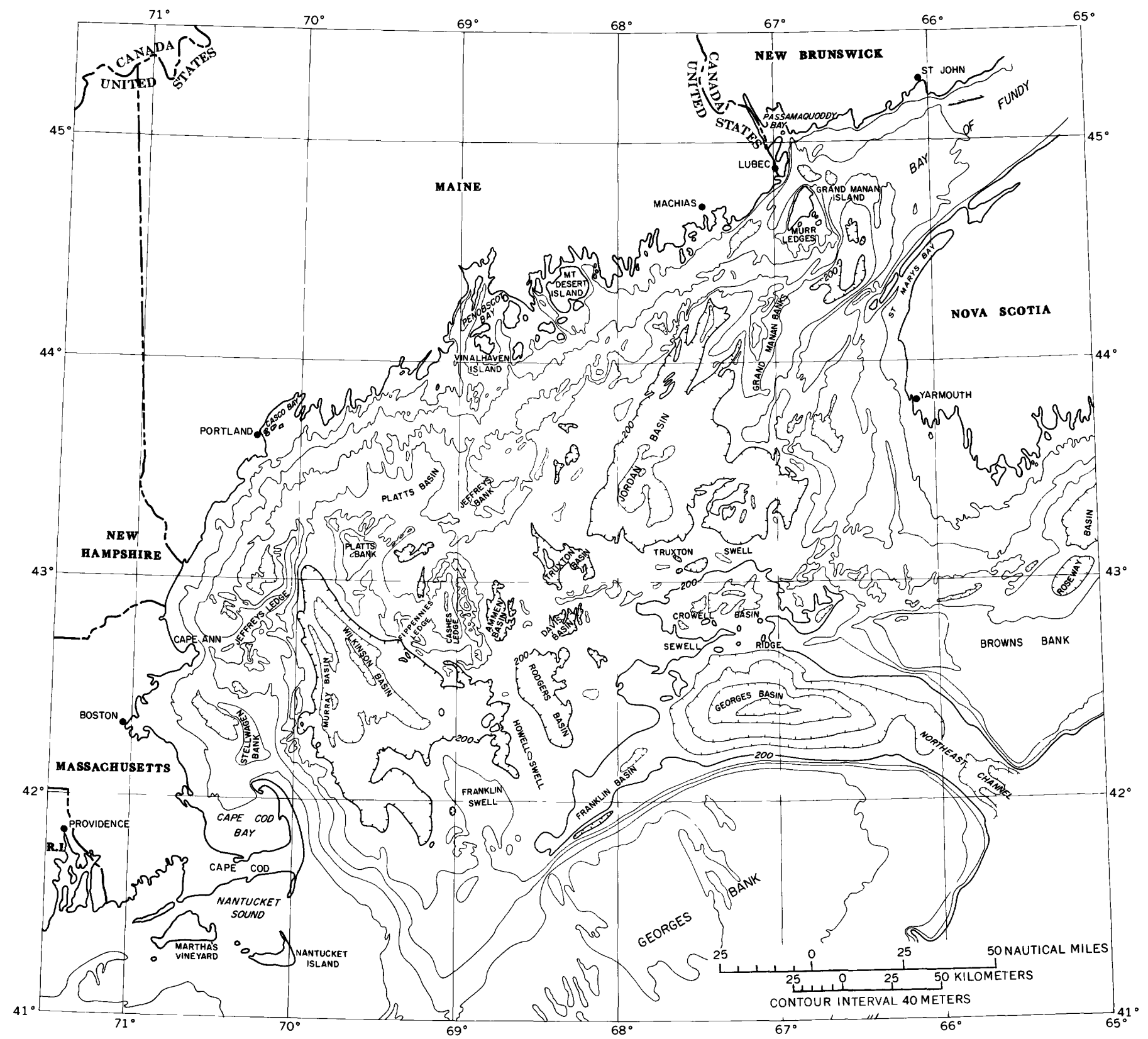

FIGURE 2.-Bathymetric and location map of the Gulf of Maine. Modified from Uchupi (1965); contour interval 40 meters.

tinuous blanket over the western quarter of the gulf, including Cape Cod Bay. These strata and post-Tertiary deposits elsewhere are underlain by a highly reflective horizon, which is probably a surface on metamorphic and igneous rocks of pre-Cenozoic age.

A seismic-refraction survey by Drake, Worzel, and Beckmann (1954) showed that much of the gulf bottom is underlain at a shallow depth by an interface which is characterized in most places by a compressional-wave velocity of about $6.0 \mathrm{kmps}$ (kilometers per second). In two areas in the western part of the gulf, the velocity along this interface ranges from 4.6 to $5.5 \mathrm{kmps}$. Drake, Worzel, and Beckmann (1954) also described a 3,000-meter-thick unit having a velocity of $4.5 \mathrm{kmps}$ in the area west of Yarmouth, Nova Scotia, and units having a velocity of $4.0 \mathrm{kmps}$ and thicknesses of as much as $500 \mathrm{~m}$ in two localities north and east of Cashes Ledge (fig. 2 ). They concluded that the velocity of $6.0 \mathrm{kmps}$ was anomalously high and related to a "subbasement" rock of an unknown nature. The velocities of 4.5 to $5.5 \mathrm{kmps}$ were considered typical for a wide variety of igneous and metamorphic rocks. By com- 
parison with measured velocities in other areas, the rock unit with a velocity of $4.0 \mathrm{kmps}$ was believed to be most probably of Triassic age (Drake and others, 1954). Uchupi (1966), however, observed that this rock unit did not have the seismic-reflection characteristics typical of Triassic rocks elsewhere and suggested that it is "mildly metamorphosed" rock of Paleozoic age. Drake, Ewing, and Sutton (1959) showed that, in contrast to the gulf, the neighboring banks are underlain by as much as $3,000 \mathrm{~m}$ of low-velocity strata. These strata appear to be thickest near the central part of the banks and thin gradually seaward but more rapidly landward.

Malloy and Harbison (1966) reported detailed magnetic and continuous seismic profile measurements over a large area in the northeastern part of the gulf. They used magnetic anomalies and bedrock morphology to infer the distribution of "tightly folded crystalline Paleozoics" and Triassic sediments and to delineate several fault zones in that part of the gulf. In particular they identified an arcuate magnetic anomaly which they attributed to a ring dike like the ones of Maine and New Hampshire.

Schlee and Pratt (1970) studied the distribution of pebbles of distinctive lithology obtained in hauls from the gulf bottom. They concluded that gross bedrock types could be predicted for parts of the gulf. Their results were as follows: Igneous and metamorphic rocks are prevalent in the western gulf, felsic rocks being present near southeastern Massachusetts and mafic rocks near Cape Ann, Mass., and the New Hampshire coast; coarsely crystalline pink granite occurs southwest of Mount Desert Island, Maine; sedimentary rocks similar to those of Triassic age extend from the Bay of Fundy to Mount Desert Island; spotted schist, probably correlative with rock of Ordovician age in Nova Scotia, is present in the offshore region near Yarmouth, Nova Scotia; felsite occurs west of Yarmouth and extends north to St. Marys Bay. In the central part of the gulf, the gravel in the hauls was too sparse to give indicative results. The only known sample of crystalline rock from outcrop in the gulf was obtained by a dive to Cashes Ledge (fig. 2) the shallowest feature of the central gulf. Toulmin (1957) identified the rock as peralkaline granite, probably of Mesozoic or Paleozoic age.

Submarine gravity profiles by Worzel and Shurbet (1955) revealed that the average Bouguer gravity field over the gulf is about 20 milligals higher than that (about 0 mgal) of the surrounding land area. They concluded that the Gulf of Maine is a flooded continental block.

A preliminary analysis of a deep seismic-refraction profile from the center of the gulf to the interior of Maine by Steinhart and others (1962) indicated that a range of velocity models of the crust could be derived from the traveltime relations of the compressional-wave velocities. All the models showed a velocity of about $6 \mathrm{kmps}$ in the upper crust, a velocity of about $7 \mathrm{kmps}$ in the lower crust, and a Mohorovičić-discontinuity velocity of $8 \mathrm{kmps}$ at a depth of about $40 \mathrm{~km}$. It was demonstrated that the velocity changes, including that at the crust-mantle interface, could be either steplike or smooth.

\section{GEOLOGIC FRAMEWORK}

The northern Appalachians (fig. 1) form a broad belt of stratified geosynclinal rocks between the Precambrian cratonic core of North America on the northwest and the Atlantic Ocean on the southeast. Most of the strata are of early to middle Paleozoic age and have been regionally metamorphosed. A wide variety of igneous rocks, mainly intrusive masses of felsic composition, has been emplaced in the stratified rocks throughout the region. Regional geologic trends, shown by the axes of major folds and the areal distribution of rock units, are mostly northeast, in accord with the predominant trend of the Appalachians. Rocks of Precambrian age form the cores of structural uplifts in the western part of the region and underlie several widely separated areas in the east. Rocks of Carboniferous or younger age, some of which are locally metamorphosed, occur in the southeast and over a broad area around the Gulf of St. Lawrence.

The broad expanse of eugeosynclinal rocks of New England provide few clues to the geology of the Gulf of Maine except that it may have been a source region for part of the sediments of the eugeosyncline (Zen, 1968). The exposures of rocks of late Precambrian or early Paleozoic age northeast and southwest of the gulf suggest that the intervening region may be underlain by rocks of similar age. In this setting the bedrock of the gulf would form a structural high along the oceanward side of the eugeosyncline much as does the Green MountainSutton Mountain anticlinorium on the opposite (cratonic) side.

In the coastal areas of Maine, extensive exposures of volcanic rocks indicate that volcanism was prevalent during some periods along the northwest mar- 
gin of the gulf (Hussey, 1968; Boucot, 1968; Gates, 1969). Chapman (1962) concluded that a complex of mafic and felsic rocks occupying most of the eastern Maine coast extends as much as $30 \mathrm{~km}$ into the gulf. In southern New England, major rock units strike into the gulf and may emerge in Maine, but positive ties between the two regions have not as yet been made. In Nova Scotia, regional trends parallel the northwest coastline, but broad folds on the west trend southwest to south into the gulf.

In an early report on the coastal region of New England, Johnson (1925) postulated that a major fault system was located within the Gulf of Maine. Bell (1967) described a great imbricate overthrust fault trending northeast into the gulf in the vicinity of Cape Ann, Mass. Wilson (1962) used the location of faults in Newfoundland, Nova Scotia, Prince Edward Island, and Massachusetts, and Johnson's (1925) Gulf of Maine fault system as the basis of proposing the Cabot fault (fig. 1), "an Appalachian equivalent of the San Andreas Fault." He suggested that the structure may have been linked to the Great Glen fault of Scotland as a continuous feature before continental drifting began. Indications of displacement on the fault were considered meager, although there was some evidence of left-lateral movement.

Belt (1968) described a series of thick basin deposits of Carboniferous age that extend in a narrow sinuous zone from Newfoundland to the Bay of Fundy and that are near or coincident with the Cabot fault. On the basis of the geometry and character of these deposits, he proposed the existence of a major rift system that was active from Late Devonian to Triassic time. Webb (1968) assembled more detailed data on the individual elements of the Cabot fault; he concluded that it was active during the same period as Belt's rift system and has as much as $190 \mathrm{~km}$ of right-lateral movement. Gates (1969) established the beginning of major deformation in the region of the Cabot fault as Early Silurian, on the basis of associated volcanic rocks of that age in Maine and New Brunswick.

From a regional standpoint, therefore, it seems reasonable that a major structure of continental dimensions passes through the Gulf of Maine. The precise nature of the structure is not clear, but the study of Belt (1968) indicates that Carboniferous deposits are associated with it, and therefore these deposits may be present in the gulf. This conclusion is supported by the presence of Carboniferous deposits in southern New England, which are on regional strike with those of the Bay of Fundy. A major implication of the conclusions of Wilson (1962) and Webb (1968) is that the Gulf of Maine region may not be directly related to the Appalachian region to the northwest because of major offset on a transcurrent fault separating the two regions.

\section{GEOPHYSICAL INTERPRETATION}

GRAVITY AND AEROMAGNETIC SURVEYS

Gravity data at sea are based on both bottom measurements and surface-ship measurements as described by Yellin (1968). North- and east-oriented ship tracks were spaced at about $16 \mathrm{~km}$, and bottom stations were measured on an underlying 16-km grid that generally coincided with the ship tracks. Data from bottom stations cover about 80 percent of the area of the surface measurements. Surface data were averaged for 5-minute (time) intervals, which is equivalent to about a $2-\mathrm{km}$ spacing; these data are internally consistent within about 2 mgal. There is a 3 -mgal discrepancy between surface and bottom measurements which seems to be a measure of systematic error in the surface-ship survey (Yellin, 1968). An elevation correction, based on a density factor of 2.8 grams per cubic centimeter, was used to reduce the data to the Bouguer gravity field. Contours are drawn on surface data supplemented by bottom data in areas outside the surface network. Land data are from Kane and Bromery (1966), Bromery (1967), Joyner (1963), and from unpublished measurements made by Kane on islands in the summer of 1968 .

Aeromagnetic data for the Gulf of Maine and the adjoining United States are adapted from an aeromagnetic map of the eastern continental margin of the United States (Taylor and others, 1968). Flight-line spacing was about $8 \mathrm{~km}$; flight altitude was $200 \mathrm{~m}$ over ocean and 500 to $800 \mathrm{~m}$ over land. Estimated accuracy of flight-line position is $\pm \mathbf{1 . 5}$ $\mathrm{km}$, and the maximum error is $3 \mathrm{~km}$. Aeromagnetic data for parts of eastern Canada were compiled from the series of maps published by the Geological Survey of Canada (1968). Flight lines for these maps were $0.8 \mathrm{~km}$ apart and at altitudes of 150 to $300 \mathrm{~m}$; some coverage was taken from shipboard surveys.

\section{LITHIC UNITS AND ANOMALIES}

Relations between physical properties and rock types are generally ambiguous, but under some conditions the correspondence between geophysical anomalies and specific rock types is fairly well established. As an example, well-defined gravity lows 
(15 to $50 \mathrm{mgal}$ in amplitude) in regionally metamorphosed terrane are frequently associated with felsic plutons, and sharp gravity highs (greater than $15 \mathrm{mgal}$ in amplitude), with mafic or ultramafic plutons. This correspondence holds between Bouguer gravity anomalies and geologic features in Maine (Kane and Bromery, 1968) and in some parts of Nova Scotia and New Brunswick (Garland, 1953). Elsewhere in Nova Scotia and New Brunswick, however, gravity lows are caused by relatively low-density sedimentary rocks of Triassic and (or) Carboniferous age, and by a deposit of salt in one place. For the anomalies cited above, the critical interpretive guide was the identification of the source with bedrock exposures or with drill-hole information. Such a guide is obviously lacking in water-covered areas so that a twofold ambiguity must be recognized for gravity lows in the Gulf of Maine. Bott (1962) has proposed anomaly-shape criteria to distinguish between the two types of gravity lows, but his method requires a greater precision than is inherent in the gravity data for the gulf. The plan shapes of some anomalies may provide insight into their causes, although such insight is unlikely to be definitive. In contrast to interpretation of gravity lows, the identification of a mafic or ultramafic mass as the source of a steep-gradient high-amplitude gravity high is relatively unambiguous.

The causes of low-amplitude low-gradient gravity anomalies can be interpreted with less assurance. Kane and Bromery (1968) have concluded that most low-amplitude highs over the regionally metamorphosed bedrock underlying Maine are caused by volcanic rocks of mafic composition. In one area of Maine moderate gravity lows are associated with volcanic centers typified by felsic rock (Rankin, 1968). Where porosity is a density factor, low-amplitude gravity lows may indicate the presence of low-density sediments.

An established practice for the interpretation of aeromagnetic maps is to assume that anomalies are caused by igneous rocks. The primary magnetic mineral giving rise to the anomalies is magnetite, although anomalies of moderate amplitude are sometimes caused by other minerals, including sulfides. As a rule, magnetite is associated more frequently with mafic minerals than with felsic minerals so that intense anomalies (amplitude greater than 500 gammas at an altitude of $300 \mathrm{~m}$ ) are usually attributed to mafic and ultramafic rocks. Although felsic plutons are generally nonmagnetic, they commonly have magnetic aureoles which are caused by more magnetic border phases or by al- tered country rock (Allingham, 1961). Sedimentary rocks are typically nonmagnetic so that flat magnetic fields are associated with thick sedimentary deposits. An iron-formation, however, gives rise to very intense anomalies particularly where it is intruded by igneous rocks. Regional metamorphism is also a factor in rock magnetism (Reed and others, 1967), but the relationship is as yet incompletely understood. There are many exceptions to the magnetism-lithology relations noted here so that they constitute, at best, very general guidelines for interpretation of geophysical data. At present, the correspondences between magnetic anomalies and rock units that are observed in the region of study seem to offer the best aids to the interpretation of aeromagnetic maps. This practice is followed in this report.

\section{QUANTITATIVE ANALYSIS}

As a primary step in the interpretation of gravity anomalies, Kane and Bromery (1968) have suggested the calculation of the maximum depth to top of source (Bott and Smith, 1958; Bancroft, 1960) and the minimum thickness of source. The maximum depth is given by

$$
D_{\max }=K \frac{A}{S_{\max }},
$$

where $D_{\max }=$ maximum depth to top of source, in kilometers,

$K=$ constant, less than 1 , depending on shape of source,

$A=$ anomaly amplitude, in milligals, and

$S_{\max }=$ maximum horizontal gradient of anomaly, in milligals per kilometer.

The minimum thickness of source is given by

$$
T_{\min }=\frac{A}{0.042 d},
$$

where $T_{\min }=$ minimum thickness, in meters,

$$
\begin{aligned}
A & =\text { anomaly amplitude, in milligals, and } \\
d & =\text { maximum density contrast, in } \mathrm{g} / \mathrm{cm}^{3} .
\end{aligned}
$$

Calculation of these quantities is a preliminary step in any gravity analysis, and subsequent refinements usually require either well-defined gravity gradients, reliable density data, additional information on the anomaly source, or a combination of these. The knowledge of gravity gradients and probable density contrasts for the Gulf of Maine is fairly limited so that the above formulas alone are gener- 
ally sufficient for the quantities that may be deduced from the gravity data.

Analysis of aeromagnetic anomalies in terms of shape and magnetic properties of the source is more difficult than analysis of gravity anomalies, partly because of the complexity of the magnetic field arising from a distribution of dipoles and partly because both remanent and induced components of magnetism may be present. An empirical depth relation (Vacquier and others, 1951), similar to that for the gravity method, is used for a few magnetic anomalies in areas where magnetic rocks seem to be deeply buried.

\section{REGIONAL GRAVITY}

The Bouguer gravity field increases in value from the surrounding coastal areas into the interior of the Gulf of Maine where, except for three locations, it is everywhere positive (pl. 1). The background gravity field of about $20 \mathrm{mgal}$ is highlighted on plate 1 by shading of the +15 - to +25 -mgal contour interval. The shaded area persists over the whole surveyed region of the gulf and is generally characterized by a sparsity of contours. Superposed on the background gravity is a complex group of positive and negative anomalies which taken together have an overall northeast trend. The general appearance of the anomalies is similar to that on land, suggesting similar causes-near-surface masses of felsic and mafic igneous rocks, and possibly sedimentary rocks, set in a matrix of metamorphic rocks.

The lack of contours in the shaded area indicates that the bedrock underlying it has a relatively uniform density. The uniform background gravity level of the gulf, though higher, is similar in geometry to the three regional gravity levels described for the interior of Maine by Kane and Bromery (1968), who showed that the maximum depth to the tops of the sources giving rise to the change in gravity levels was less than $6 \mathrm{~km}$. No specific cause was advanced for the change in gravity levels, but it was pointed out that, in the southwestern part of the State (northwest of Portland), these levels were replaced by a rather uniformly sloping regional gradient. Kane (1968) suggested that the uniformly dipping regional gravity field is related to the lithology of the rocks in the high-grade metamorphic (sillimanite) zone that underlies the area.

The average background gravity level of the coastal area of Maine was estimated by Kane and Bromery (1968) to be about -5 mgal. The gravity gradient between the background gravity level over the coastal area and that over the gulf can be seen most clearly northeast of Portland (on pl. 1), and has a value of about $1 \mathrm{mgal} / \mathrm{km}$. The maximum depth to the density contrast causing the change in gravity levels is calculated to be about $8 \mathrm{~km}$, on the basis of the formula on page B 6 where $K=1 / \pi$ (plate-shaped source), $S_{\max }=1 \mathrm{mgal} / \mathrm{km}$, and $A=25$ mgal (+20 mgal over the gulf and $-5 \mathrm{mgal}$ on land). Thus the higher gravity level over the gulf is caused by a rock mass whose top is shallower than $8 \mathrm{~km}$ and whose density is greater than the crustal rocks at similar depths in the adjoining land region. A regional gradient like that over the high-grade metamorphic zone of southwestern Maine is not apparent in the gulf, suggesting that a similar zone is not present in the gulf.

Gravity values on the west coast of Nova Scotia exceed $+20 \mathrm{mgal}$, indicating that the high gravity level over the southwestern two-thirds of the gulf extends over the unsurveyed area to the east. An onshore example of high gravity level, other than levels over exposures of mafic rock, is in southeastern New Brunswick (northeasternmost quadrant of pl. 1) where a level greater than $+15 \mathrm{mgal}$ is associated with bedrock of Precambrian or early Paleozoic age. Gravity levels exceeding $+15 \mathrm{mgal}$ also are present over broad areas of exposures of similar age in northeastern Nova Scotia (Garland, 1953). The correlation of broad areas having high gravity levels with bedrock of early Paleozoic or Precambrian age is not conclusive, but it does suggest a plausible explanation for the high gravity level of the gulf and the shallow depth of the source of the gravity level. Presumably, the crustal block underlying the gulf is a structural high in which older basement (Precambrian?) and deeper denser crust is uplifted relative to the surrounding land regions. Other explanations are possible, including a gulf crustal block that has a different composition from that of the land regions, or bedrock that has a comparatively high proportion of mafic lithic units. Whatever the precise cause of the high gravity level, it differentiates the gulf region as a distinctive crustal unit.

\section{LOCAL GRAVITY ANOMALIES}

Land Areas

Many examples of the gravity anomaly-lithology correlations, cited in the section on gravity analysis, are shown in the land regions around the gulf. Gravity lows are present over most of the areas of felsic bedrock except for the area between Cape Ann, Mass., and Portland, Maine. Gravity highs are present over mafic exposures in eastern Maine and 
northeastern Massachusetts. In New Brunswick, relatively lower gravity is associated with a region underlain by porous sedimentary rocks of Carboniferous age but, in Rhode Island and Massachusetts, no apparent anomaly is associated with indurated and partly metamorphosed strata of similar age.

The absence of anomalies over exposures of felsic and mafic rocks is assumed to imply that the mapped rocks are relatively thin and lack sufficient volume to cause appreciable anomalies. The absence of an anomaly over the rocks of Carboniferous age in Rhode Island and Massachusetts is probably due to the lack of porosity caused by induration and metamorphism and the consequent elimination of an effective density contrast. Gravity anomalies in the gulf therefore indicate the presence of igneous rocks only where they are thick and of sedimentary rocks where they are both thick and porous.

Coastal Areas

A series of gravity highs generally associated with underlying exposures of mafic rock occur along the coastal margin of the gulf from Lubec, Maine, to Cape Cod (fig. 3). Although a high gravity level is present over the gulf, the coastal anomalies can be differentiated from it by their closure. The specific occurrences are the following: The gabbroic phase of the Bays of Maine igneous complex (Chapman, 1962), underlying much of the eastern coast of Maine, and associated gravity highs; mafic exposures on Monhegan Island, Maine, and a gravity high extending into the gulf; a limited exposure of gabbro and a much broader gravity high at Cape Neddick, Maine; a gabbro exposure at Cape Ann, Mass., and a probable lateral extension of it at depth shown by an extensive gravity high; and an unexposed body shown by gravity and magnetic highs (Griscom and Bromery, 1968) in western Cape Cod. A gravity high is also indicated southeast of Portland, Maine, but it may be a partial manifestation of the high gravity level underlying the gulf.

The rate of incidence of the mafic masses at the coast seems too high to be coincidental, especially as major mafic masses are relatively rare inland. The range in age of the plutons is large, probably as great as from early Paleozoic to Mesozoic. The presence and time range of the plutons indicate that a major crustal structure, persisting from Precambrian to present, occurs in the vicinity of the coast. The structure may be the result of adjustments between the distinctive crustal block underlying the gulf (described in an earlier section) and the crust of the surrounding land regions.

\section{Gulf of Maine Region}

The local gravity anomalies of the gulf region have relative amplitudes as great as $\pm 30 \mathrm{mgal}$ and gradients as large as $6 \mathrm{mgal} / \mathrm{km}$. In order to stay above the margin of probable error, the following analyses are limited to those anomalies that are at least $\pm 10 \mathrm{mgal}$ in amplitude. To facilitate discussion, anomalies are labeled in Roman numerals, I through $\mathrm{V}$ for negative anomalies, and $\mathrm{X}$ through $\mathrm{XV}$ for positive anomalies; subdivision of groups of anomalies is shown by suffixed letters. Note that the term "amplitude," when used below, refers to the peak value of an anomaly relative to the background gravity field.

Reasonable approximations for the densities of probable bedrock types are as follows: Carboniferous sedimentary rocks, $2.5 \mathrm{~g} / \mathrm{cm}^{3}$; felsic rocks, 2.6 to $2.7 \mathrm{~g} / \mathrm{cm}^{3}$; mafic rocks, $3.0 \mathrm{~g} / \mathrm{cm}^{3}$; and metamorphic host rock, $2.8 \mathrm{~g} / \mathrm{cm}^{3}$ (Kane and Bromery, 1968). The maximum probable density contrast is $0.3 \mathrm{~g} / \mathrm{cm}^{3}$, which leads to a minimum thickness-amplitude relation (using the minimum-thickness formula given on p. B6) of $80 \mathrm{~m} / \mathrm{mgal}$. Because the density contrast enters as a simple factor, the relation may be adjusted for a preferred density contrast by using a simple ratio.

The gravity effect of unconsolidated or semiconsolidated strata in the survey region may be as much as $5 \mathrm{mgal}$, but the effect is much less in most places. This effect is considered to be a negligible factor in the discussion which follows.

The amplitudes and shapes of the gravity anomalies over the gulf appear to be similar to those on land, except that contours are somewhat smoother and gradients are less steep over the gulf. The difference in appearance is due, at least in part, to the larger spacing and lesser precision of the marine gravity measurements. Because of the established correlations on land, the gravity highs are assumed to be caused by masses of mafic igneous rock, and gravity lows, by masses of felsic igneous rock or of porous sedimentary rock. It is also assumed that the widespread Acadian (Devonian) regional metamorphism of the northern Appalachians extends throughout the gulf, so that low-density (porous) sedimentary strata are restricted to a Carboniferous or younger age. The investigation by Uchupi (1966) seems to rule out any thick deposits of lowdensity strata of post-Paleozoic age, except at two locations (near the mouth of the Bay of Fundy and in Georges Basin) which are outside the region of the gravity survey. Consideration of sedimentary sources for gravity lows is thus restricted to rocks 
of late Paleozoic age and, because of the lack of rocks of known Permian age in the region, further restricted to rocks of Carboniferous age.

Anomaly I, the broadest negative anomaly in the gulf, is a composite feature, consisting of three closures set in a large irregular low. Part of the irregularity reflects some small positive anomalies within the low which do not show at the 5-mgal contour interval. The amplitude at the lowest closure is more than $-20 \mathrm{mgal}$, indicating that the minimum thickness of the source (sedimentary) in that area is more than $1,600 \mathrm{~m}$. For a felsic igneous source having a density contrast of about $0.15 \mathrm{~g} / \mathrm{cm}^{3}$, the minimum thickness would be about $3,000 \mathrm{~m}$. The horizontal outline of the anomaly is more complex than outlines over individual felsic plutons, although the complexity might be attributed to a group of adjacent plutons like those in the eastern coastal area of Maine. In particular, the narrow linear part of the low is suggestive of a rift structure filled in with low-density sedimentary rocks. The cause may be a multiple source consisting of sedimentary rocks deposited in a terrane underlain by felsic plutons.

Several linear aeromagnetic highs (shown on pl. 2 along with trace of gravity closures), trending southwest, are present within the gravity low. A small gravity high (not apparent at the 5-mgal contour interval) correlates with the most intense of the aeromagnetic anomalies, indicating the presence of a correspondingly small linear mafic or ultramafic mass. The anomalies are not well enough defined to estimate the dimensions of the high-density source precisely, but the aeromagnetic anomaly indicates that it is near the surface, and the gravity anomaly indicates that it may be more than $1 \mathrm{~km}$ in width. The magnetic field is generally flat in the area of the three negative closures in the gravity field. The general appearance of the magnetic field over the gravity low is not like that over most felsic masses in Maine, although individual magnetic lineaments occur within some felsic plutons-for example, the Katahdin batholith (Boucot and others, 1964).

The area east of the 0-isogal closure is underlain by a rock unit that is about $500 \mathrm{~m}$ thick and has a compressional-wave velocity of about $4.0 \mathrm{kmps}$ (Drake and others, 1954). This velocity is low for felsic igneous rock but is typical for many types of sedimentary rock. The amplitude of the gravity anomaly would imply a thicker section of sedimentary rocks, but the seismic profile may have crossed an area where they are thinner. In general, most evidence favors sedimentary rocks as the source, but additional exploration is needed to resolve the cause or causes of the gravity feature.

Anomaly II is a broad steep-gradient feature with an amplitude of more than $-30 \mathrm{mgal}$, the largest negative amplitude in the gulf. The anomaly opens to the southwest beyond the limits of the gravity survey. The magnetic field is flat near the central part of the low but is anomalous along its margins. As pointed out earlier (p. B6), magnetic aureoles are commonly observed on the peripheries of felsic plutons. The large amplitude also suggests a felsic igneous pluton, although sedimentary rocks cannot be ruled out.

The anomalies in the regions marked IIIa and IIIb resemble gravity anomaly $I$ in their irregularity and amplitude. Magnetic anomalies are present but are not as prevalent and intense as over gravity anomaly I. Part of the low, north of Cape Cod between the 5and 10-mgal lines, coincides with an area of high seismic reflectivity outlined by Hoskins and Knott (1961). The source could be sedimentary rocks, a felsic pluton, or possibly a composite of both.

Anomalies IVa through IVf are similar in size, shape, amplitude ( -10 to $-20 \mathrm{mgal}$ ), and gradient. The shape similarities are in part the result of incomplete data, for two are only partly defined and two are crossed by only one profile. The center of gravity low IVa is magnetically low and relatively flat; some small magnetic anomalies are grouped on its periphery. A seismic profile (Drake and others, 1954) on the northwest rim of the gravity low shows the presence of 400 to $500 \mathrm{~m}$ of rock having a compressional-wave velocity of $4.0 \mathrm{kmps}$. The pattern of the magnetic field favors an igneous source, whereas the seismic data favor a sedimentary source, at least in part. The stations in the area of anomaly IVb are not adequate to define it completely, but a lower gravity field is indicated by several measurements along the margins of the gravity anomaly. The magnetic field is anomalous throughout the gravity low, particularly along its southeast side. Joyner (1963) reported the presence of gneissic granite from islands in the southwestern part of the low, which would appear to confirm a felsic igneous source. Anomaly IVc is defined by gravity measurements made on a group of islands. A magnetic low, which coincides with the center of the gravity low, is bordered by a semiarcuate magnetic high of moderate amplitude. The islands are underlain by felsic intrusive rock so that the source of the gravity low is a felsic pluton. The magnetic high may arise from a more mafic border phase or from altered host rock. 
Anomaly IVd is a well-defined steep-gradient low on the south but is poorly defined in the north. The magnetic field is flat over the southeastern twothirds of the gravity anomaly but shows southwesttrending linear features to the northwest. Anomalies IVe and IVf are broad gravity features based mainly on single profiles. A low-gradient linear magnetic high trends southwest through the center of IVe; the south part of a broad magnetic high occurs over part of IVf. The geophysical data in the areas of IVd, IVe, and IVf are generally not adequate to distinguish between a felsic igneous and a sedimentary rock source. The equidimensional shape of the anomalies favors an igneous source, but the shape is at least partly the result of insufficient data.

Anomaly $\mathrm{V}$ is an elongate feature of moderate negative amplitude. The magnetic field over gravity anomaly $\mathrm{V}$ is relatively low and flat, having several small-amplitude highs striking transverse to the trend of the gravity anomaly. The elongate character of the gravity anomaly is more typical of folded sedimentary rocks than of felsic plutons, although at least one example of a felsic pluton having such a shape occurs in Maine (Pavlides, 1965).

As a group, the gravity highs are simpler in form and more discrete in setting than are the gravity lows. These characteristics of the group, coupled with the close correspondence of mafic exposures and gravity highs on land, make interpretation more straightforward.

Anomaly $\mathrm{X}$ is a type gravity anomaly for a large mafic pluton. It has a relative amplitude of more than $20 \mathrm{mgal}$ and a coincidental broad magnetic anomaly about 2,000 gammas in amplitude. The gravity anomaly is closely similar in amplitude, horizontal shape, and areal extent to that over a gabbro pluton in central Maine (Kane, 1960; Kane and Bromery, 1968). On the basis of a density contrast of $0.2 \mathrm{~g} / \mathrm{cm}^{3}$, the minimum thickness is calculated to be nearly $3,000 \mathrm{~m}$; the steep gradients indicate that the top of the source is near the surface of the bedrock.

The peaks of both the gravity and magnetic anomalies are over the southeastern part of Cashes Ledge, a submarine ridge whose shallowest peak is the source of a sample of peralkaline granite (Toulmin, 1957). The mafic source, clearly indicated by the gravity and magnetic data, apparently is overlain by felsic rock, possibly a differentiate. The magnetic anomaly extends considerably farther west than the gravity anomaly_-indicating that an additional source, possibly moderately magnetic fel- sic rock, contributes to the magnetic high. The geology of the area of Cashes Ledge may be similar to that of Cape Ann, where granite overlies what appears to be a broad subsurface extension of the Salem Gabbro-Diorite.

The double-peaked broad gravity high underlying the area marked XI is much larger in areal extent than any positive anomaly observed in nearby land areas. The relative amplitudes of the peaks are high (more than $20 \mathrm{mgal}$ ), but the gradients are somewhat low. Linear magnetic anomalies, mostly of low or moderate amplitude, are present in the area of the high, but they seem too small in area to be caused by the same source. The unusual appearance of the anomaly, the lack of an associated magnetic anomaly, and the low gradients suggest that the source may not be directly related to near-surface geologic features but may be deeper in the crust.

Anomaly XII is a broad, elongate, in part steepgradient feature having an amplitude of about 20 mgal. It is separated from the gravity highs over gabbroic rocks of the Bays of Maine igneous complex by an area of moderately low gravity (indicated by saddles between the land highs and gulf highs). A zone of intense magnetic anomalies corresponds with the gravity high, the broadest and most intense of the magnetic features being over the northeast part of the gravity high. This intense magnetic anomaly is shown by Malloy and Harbison (1966) to be a ringlike feature that coincides with a faint morphologic ringlike structure in the bedrock. The morphology, magnetic anomaly, and gravity anomaly of this area are similar to those over the Merrymeeting stock in New Hampshire (Joyner, 1963), although the Merrymeeting stock is somewhat larger in area.

The mapping of anomaly XII is based wholly on sea-floor measurements spaced on a $16-\mathrm{km}$ grid, so details of the anomaly are lacking. The present measurements suggest that it may be a composite of two broad equidimensional highs which are $20 \mathrm{mgal}$ in relative amplitude and alined along a northeast axis. The northeasternmost peak would fall near the ringlike feature mapped by Malloy and Harbison (1966). The source of the gravity anomaly appears to be either a broad mafic mass elongate to the northeast or two circular masses which are alined in that direction.

The highest Bouguer gravity value measured in the Gulf of Maine is the peak of anomaly XIII. It is a well-defined isolated high with a relative amplitude of 30 mgals, and it coincides with a sharp magnetic high which is elongate northeastward. To 
the northeast a second partly defined gravity high of about 20-mgal amplitude correlates with a moderate elongate magnetic anomaly. The magnetic anomalies are much smaller in areal extent than the gravity anomalies and may reflect near-surface extensions of larger deeper masses. The anomalies most probably indicate mafic intrusions.

Anomaly XIV is a broad northeast-trending feature between two gravity lows. The relative amplitude is about $15 \mathrm{mgal}$ but appears higher because of the adjoining lows. A group of small magnetic anomalies is present along the northwest flank of the high, but the magnetic field is flatter and at a lower level in the central and southeast parts. The anomaly could be caused by a broad mafic pluton of moderate thickness or by a sequence of stratified rocks that contains a considerable percentage of mafic volcanic units.

Anomalies XVa through XVd are all of relatively low amplitude (10 to $15 \mathrm{mgal}$ ). The linear southwestern part of anomaly XVa correlates closely in trend and location with a fairly intense linear magnetic high, whereas the northern part of the gravity anomaly is marked by a series of low-amplitude magnetic features. The northern part of the gravity anomaly extends to the gabbro exposures of Monhegan Island, so the source of the entire high is probably a mafic pluton. Anomaly XVb encompasses a group of magnetic highs of moderate intensity, indicating the presence of mafic plutonic or volcanic rocks or possibly both. A small gravity high (not labeled) just east of XVb coincides with an intense magnetic high and indicates the presence of a small mafic pluton.

Anomaly XVc is a fairly broad elongate feature in the area of a low-level and slightly anomalous magnetic field. Anomaly XVd is an areally small fairly sharp high with no apparent associated magnetic feature. The geophysical characteristics of these anomalies are not critical enough to indicate their sources, although the elongate shape of XVc suggests a volcanic source and the equidimensional shape of XVd suggests a plutonic source.

\section{AEROMAGNETICS \\ Regional Magnetic Field}

The main component of the earth's geomagnetic field has been removed from the aeromagnetic data (Taylor and others, 1968, p. 755) so that magnetic levels may be compared over widely separated areas (pl. 2). The magnetic field of the Gulf of Maine region has the highest average level and the most intense anomalies of any region along the Atlantic coast of the United States (Taylor and others, 1968). As a group, the anomalies have a northeast trend approximately parallel to the principal trend of the Appalachians, though single anomalies and small groups of anomalies commonly have divergent trends. Some broad anomalies have lateral extents of as much as $50 \mathrm{~km}$; amplitudes relative to nearby magnetic levels reach a maximum of more than 2,000 gammas. Distinctive contrasts in magnetic expression are apparent between large areas of the gulf region, which indicates corresponding contrasts in the geology of the bedrock underlying these areas. On plate 2 , areas of major contrast in magnetic expression are outlined in solid heavy lines; some subordinate divisions are shown by dashed lines. In the following discussion, the anomaly-lithology relations observed in the land areas around the gulf serve as the principal guidelines in interpreting the magnetic anomalies in the water-covered areas.

\section{Land Areas}

A highly anomalous high-level magnetic belt extends from southern New Brunswick (northeasternmost corner of map) to Mount Desert Island, Maine. North of the eastern part of the Bay of Fundy, the high-level magnetic field (greater than 1,000 gammas) and local intense positive anomalies coincide with an area underlain by rocks of Precambrian age. These rocks and rocks of similar age, described in a later section, are made up of a wide variety of volcanic and plutonic igneous rocks as well as of metamorphosed sedimentary rocks. Farther north, a southwest-trending linear high (enclosed by 1,000-gamma contours) corresponds on the northeast to a structural uplift cored by Paleozoic volcanic rocks and on the southwest to a linear zone of rocks of Precambrian age. West of St. John, New Brunswick, the high-level magnetic field correlates with a major pluton which is primarily felsic in composition but which is made up in part of mafic rocks. Gravity data (pl. 1) indicate that the pluton extends to considerable depth and that its top is only partly exposed. Most of the local intense anomalies of the magnetic field over the pluton are associated with areas of mafic rock or with inliers of stratified rocks. A moderately intense linear anomaly, which trends southwest across the central part of Passamaquoddy Bay and thence south along the Maine-New Brunswick boundary, correlates with an anticlinal structure in volcanic rocks of Silurian age. In the eastern coastal area of Maine, intense equidimensional positive anomalies 
within the high-level magnetic belt correspond to mafic plutonic rock and, in some places, to felsic rock (Mount Desert Island area and west of Passamaquoddy Bay). Gravity anomalies, however, indicate that the felsic rock is thin and that it may be underlain by rock that is mafic in composition. At the southwest end of the gulf, broad magnetic anomalies of high level are present at Cape Ann, Mass., and Cape Neddick, Maine, in the vicinity of relatively small areas of mafic rock. Gravity data, however, indicate that mafic masses widen with depth and attain horizontal extents that are comparable with the areas of the magnetic anomalies.

Inland in Maine a broad moderately intense magnetic high extends southwest from the vicinity of Bangor to the coast. The anomaly corresponds generally to the Knox Gneiss of Perkins and Smith (1925) which they mapped as a distinct unit because of "abundant intrusions," mostly of small areal extent. A broad magnetic high extends onshore in southwestern Rhode Island and southeastern Connecticut where it is underlain by stratified rocks cut by sheetlike felsic igneous bodies (Richard Goldsmith, oral commun., May 1969). An elongate southwest-trending magnetic anomaly of moderate intensity in central Massachusetts (westernmost magnetic high) overlies a belt of stratified rocks of Cambrian and Ordovician age which is characterized by intense migmatization (Hansen, 1956). It is not clear whether the group of anomalies described in this paragraph arises from the cumulative effect of many small magnetic sources or from a larger related magnetic source at depth. The association of the highly intruded areas of rock with broad moderately intense positive magnetic anomalies, however, seems to be a common one.

The flat parts of the magnetic field in the northeasternmost part of the map area (New Brunswick) are generally coincident with areas underlain by sedimentary rocks of Carboniferous age. To the south, the flat low-level magnetic field is associated with the Triassic strata of the Bay of Fundy region, an association which is characteristic of Triassic basins (see, for example, Bromery and Griscom, 1967). The flat magnetic field presumably reflects the thick sequence of weakly magnetic rocks that typically underlies the Triassic basins. Parts of the moderately intense positive anomalies over Grand Manan Island correlate with rocks of Precambrian age and apparently are caused by basement protruding through the Triassic strata. The magnetic field over the major felsic pluton underlying much of the Nova Scotian peninsula is low level and virtually not anomalous, whereas the field over surrounding stratified rocks of Ordovician age, though also low level, shows linear anomalies of moderate positive amplitude. The linear anomalies correlate with areas of black slate and schist which overlie an older unit made up of graywacke, quartzite, gneiss, and minor slate. The correlation indicates that the black slate and schist are moderately magnetic, whereas the older unit is virtually nonmagnetic. A noteworthy aspect of the magnetic field in Nova Scotia is the abrupt termination of the linear magnetic anomalies where the stratified rocks are cut off by the felsic pluton.

In Maine, a southwest-trending zone of low-gradient low-level magnetic field extends from about $67^{\circ} 30^{\prime}$ W., $45^{\circ} 00^{\prime} \mathrm{N}$. to about $69^{\circ} 30^{\prime}$ W., $44^{\circ} 00^{\prime} \mathrm{N}$. The zone is underlain by several large felsic plutons and by intervening areas of pelitic rocks in which volcanic rocks are typically scarce (Gates, 1969; P. H. Osberg, oral commun., May 1969). A similar zone in southeastern New Hampshire and northeastern Massachusetts is underlain by pelitic rocks in which "volcanic rocks are distinctly subordinate" (Billings, 1956). In southeastern Massachusetts and eastern Rhode Island, the magnetic field over stratified rocks of Carboniferous age and felsic plutonic rock of Precambrian or early Paleozoic age (Quinn and Moore, 1968) is generally low level and not anomalous. A fairly flat, southwest-trending, lowlevel magnetic zone also extends from northeastern Massachusetts to northern Rhode Island and northeastern Connecticut and is underlain for the most part by felsic plutonic rocks.

Some particular anomaly-lithology correlations are illustrated by examples in the area near Portland, Maine. A broad magnetic low, centered at $70^{\circ}$ $\mathrm{W}$., $44^{\circ} \mathrm{N}$., is underlain in part by a group of small felsic plutons. A gravity low (pl. 1) indicates that these plutons are exposed parts of a larger continuous subsurface felsic mass which may also give rise to the magnetic low. The broad low-gradient magnetic high that adjoins the low on the southwest is over a large expanse of felsic rock which, because of the lack of an associated gravity low, is assumed to be thin. In addition, ground magnetic profiles in this area show that numerous strongly magnetized dikes intrude the felsic rock. The magnetic high is probably caused either by the cumulative effect of the dikes or by a deeper magnetic source to which the dikes may be related. Farther south, a sharp magnetic high of moderate amplitude is over a small alkalic pluton of Mesozoic age; this association is typical for small plutons of similar age in 
the New England region (Griscom and Bromery, 1968). Small linear anomalies in the bay area east of Portland correlate with major folds in stratified rocks that are mostly volcanic in origin (Hussey, 1968).

The anomaly-lithology correlations in the land areas show that the principal causes of magnetic anomalies in this region are igneous rocks. Intense broad magnetic anomalies correlate for the most part with large masses of mafic plutonic rock. Broad anomalies of moderate amplitude appear to be associated with areas that are characterized by small but abundant intrusions. Linear anomalies correlate in many places with broad folds in volcanic rocks, where the width of the anomaly is related to the scale of the fold. Small but intense equidimensional anomalies are present over small intrusions of alkalic or mafic composition. Flat magnetic fields usually correlate with areas underlain either by thick stratified rocks, in which volcanic rocks are typically scarce, or by felsic intrusions of considerable thickness. In some places the correlations have depended on the use of gravity data to evaluate the depth extent of exposed rock units.

\section{Gulf of Maine Region}

A major contrast is apparent between the magnetic field southeast of the easternmost three en echelon solid lines on plate 2 and that of the remainder of the region. The magnetic field of the southeastern part is differentiated primarily by the low gradients of the anomalies, which indicate that magnetic rock is relatively deep. The broad magnetic highs at the south-central and southeast margins of the map (within the conspicuous 1,000gamma contours, pl. 2) are parts of the east coast magnetic high which is apparently related to the boundary between the oceanic and continental crust (Keller and others, 1954; Drake and others, 1963; Taylor and others, 1968; Emery and others, 1970). Part of Nantucket Shoals, Georges Bank, and the southwestern part of Browns Bank lie between the en echelon lines and the east coast magnetic high. (The eastern part of the east coast magnetic high is parallel to but about $40 \mathrm{~km}$ seaward of Georges Bank.) The uniform character of the magnetic field indicates that the basement (magnetic rock) is deep throughout this area. Estimates of depth of basement below sea level (Vacquier and others, 1951) are $2.8 \mathrm{~km}$ at $\alpha(0.06 \mathrm{~km}$ of water $)$ and $1.8 \mathrm{~km}$ at $\beta$ $(0.04 \mathrm{~km}$ of water $)$. These depths are in close agreement with thicknesses of low-velocity strata calculated for nearby locations from seismic refraction measurements (Drake and others, 1959, fig. 35, Portland section, sta. 66 and 59, respectively). Depths may, however, be greater in other parts of this area. In contrast to the anomaly sources in the area of the banks, the sources of magnetic anomalies for most of the remainder of the gulf region appear to be near or at the sea bottom, within the limit of resolution provided by the present magnetic data.

Magnetic anomalies, although subdued in amplitude and gradient, are present in the area of the banks. These anomalies imply that the surface underlying the low-velocity strata measured by Drake, Worzel, and Beckmann (1954) may be a terrane of igneous and metamorphic rocks like that in the more anomalous magnetic areas to the northwest. On a broad scale, the transition from high-gradient magnetic field (shallow magnetic rocks) to a lowgradient field (deep magnetic rocks) is fairly abrupt and suggests that a fault zone may be present along the inner edges of the banks. The present magnetic data, however, are not sufficient to quantify the width of the transition closely, and the slope between shallow and deep magnetic rock could be of low magnitude.

Northwest of the easternmost three en echelon lines (pl. 2), the magnetic field contains an irregularly shaped central zone of highly anomalous character (outlined by solid line) bordered on the east, southeast, and southwest by zones of relatively subdued character. On the northwest, part of the highly anomalous central zone is over land, and the entire zone is bordered by a band characterized by a low-level magnetic field in which anomalies are conspicuously absent. A secondary boundary (dashed line) within the highly anomalous central zone separates a northwest belt of intense closely spaced anomalies from a broader area in which anomalies are generally less intense and spaced at wider intervals. Although the gross contrast between parts of the magnetic field throughout the Gulf of Maine is reasonably clear, the precise location of boundaries is somewhat arbitrary. As a rule, location of magnetic boundaries in the gulf region was drawn with the intent of minimizing structural implications.

From a regional standpoint, there is a general correlation between magnetic-field expression and sea-bottom topography. The highly anomalous central magnetic zone includes most of the relatively shallow area of the central gulf, though it also includes much of Wilkinson Basin, the northern part of Murray Basin, and the deep western part of Jor- 
dan Basin. A locally flat or low magnetic field coincides with the southern parts of Murray and Wilkinson Basins, with much of Rogers Basin, Franklin and Crowell Basins, the central part of Georges Basin, and the eastern part of Jordan Basin; the lack of anomalies in these areas indicates that they could contain substantial thicknesses of nonmagnetic stratified rocks.

The belt of intense anomalies along the northwestern part of the central magnetic zone extends to land, where it coincides with the Bays of Maine igneous complex (Chapman, 1962). According to Chapman, early volcanism in this area was succeeded by a plutonic sequence in which an extensive sheet of gabbroic rocks was later intruded by stocklike masses of felsic composition. The magnetic and gravity anomalies in the land area reflect both the mafic and felsic plutonic phases of the complex but indicate that the mafic plutonic phase predominates in the coastal area of Maine. The magnetic and gravity anomalies along the magnetic belt in the gulf are similar to those on land-that is, an intermixed group of pronounced highs and lows-and imply that the complex extends southwest into the gulf. Southwest of Penobscot Bay the magnetic belt as a whole bends sharply south but returns to its original southwest trend farther southwest. The individual magnetic anomalies, however, maintain their dominant southwest trend even within the southward flexure. West of $69^{\circ} \mathrm{W}$. the magnetic anomalies are predominantly linear and may indicate that broad folds of volcanic rocks are common in this area. The magnetic belt and associated gravity anomalies appear to resume on land in the vicinity of Cape Ann, Mass., which supports Chapman's suggestion that the Bays of Maine igneous complex might extent through the gulf and emerge in the Massachusetts region (Chapman, 1962).

Two linear anomalies of exceptionally high amplitude occur on the southeast side of the belt, one 3,000 gammas in amplitude centered along $68^{\circ} \mathrm{W}$., and the other 2,500 gammas in amplitude centered just west of $69^{\circ} \mathrm{W}$. These amplitudes are significantly higher than those observed over mafic rocks in nearby areas and may indicate the presence of ultramafic rocks.

Anomalies in the remainder of the central magnetic zone (southeast of the dashed line, pl.2) are generally less intense and more widely spaced than those to the northwest. Three anomalies of broad horizontal extent and fairly high amplitude are in this area-one each in the northeast, east, and southwest extremities of the zone. The anomaly in the northeast extremity is the magnetic feature which has been attributed by Malloy and Harbison (1966) to a ringdike. The general appearance and trends of anomalies of this entire area are more random than elsewhere in the gulf, although the predominant orientation is still southwest. In general, both the magnetic and gravity anomalies indicate that plutonic rocks of mafic and felsic composition are abundant and that several of the plutons are of broad horizontal extent. The individual plutons appear to be more widely spaced, however, and broad folds of volcanic rocks more scarce, than in the magnetic belt to the northwest. The east-central part of the zone is similar in some respects to the magnetic field over the broad zone of rocks of Precambrian age in the coastal area of New Brunswick. Some magnetic anomalies, particularly the double-peaked intense high east of $43^{\circ} \mathrm{N}$., $68^{\circ} \mathrm{W}$., are similar to those over small alkalic plutons of Mesozoic age in Maine and New Hampshire.

A broad zone of flat magnetic field extends southwest from the Bay of Fundy and thence south to the vicinity of $43^{\circ} 20^{\prime} \mathrm{N}$. Trends of anomalies are southwest on the north, but change to south in the south-trending part of the zone. East of Grand Manan Island, anomalies are scarce; but over Grand Manan Island and to the west and southwest, scattered anomalies of low to moderate amplitude are present; these anomalies coincide for the most part with local bathymetric highs. Uchupi (1966) concluded that the character of seismic reflections over much of this zone was typical of strata of Triassic age. Similarly, the magnetic characteristics of this zone resemble those over other Triassic basins, where a flat magnetic field is underlain by stratified continental deposits and anomalies are underlain by exposures of diabase or by basement protruding through the stratified rocks (for example, the Buckingham area of Pennsylvania, Bromery and Griscom, 1967). The flat magnetic field extends beyond the boundaries of the Triassic strata as outlined by Uchupi (1966), indicating that these strata were deposited on a surface underlain by nonmagnetic rocks. In a similar setting in the Triassic basin, in southeastern Pennsylvania, a flat magnetic field that lies at the margin of the Triassic strata is associated with metamorphosed carbonate rocks, shales, and clastic rocks of early Paleozoic age (Bromery and Griscom, 1967).

The estimated depth to magnetic rock at the location marked $\gamma$ on plate 2 is about $3.0 \mathrm{~km}$ below sea level $(0.14 \mathrm{~km}$ of water $)$, which agrees with the thickness of rocks measured in this area by Drake, 
Worzel, and Beckmann (1954) having a moderate velocity $(4.5 \mathrm{kmps})$. These rocks may be related to a broad syncline that underlies the west coast of Nova Scotia and trends gulfward in this area. The abundant anomalies between the area marked $\gamma$ and Nova Scotia are apparently caused by the upper member of folded stratified rocks of Ordovician age which gives rise to the prominent linear anomalies on the Nova Scotian mainland.

A zone characterized by numerous anomalies, mostly of low amplitude and invariably of southwest trend, extends from northwest of Browns Bank southwest to the vicinity of $71^{\circ} \mathrm{W}$. This zone is separated from the subdued field to the northeast (over the Triassic basin and Nova Scotia) by an abrupt change in anomaly trend (indicated by a dashed line on pl. 2) from south to southwest. Northeast of Franklin Swell the magnetic anomalies are typically elongate features of small area and low intensity; gravity anomalies in the surveyed part of this area are also small in horizontal extent. Both the magnetic and gravity anomalies indicate that igneous units may be common in the area between Franklin Swell and Browns Bank but that individual plutonic units are small in areal extent compared with those in area to the northwest. The elongate magnetic anomalies suggest that broadly folded magnetic stratified rocks may also be present. An area of notably low magnetic gradients is centered near $67^{\circ} \mathrm{W} ., 42^{\circ} 30^{\prime} \mathrm{N}$., and extends southwest. Seismic measurements indicate that lowvelocity strata in this area are as thick as $1 \mathrm{~km}$ (Uchupi, 1966).

Southwest of Franklin Swell the subdued magnetic zone between the banks area and land contains several broad magnetic anomalies of moderate amplitude and several areas of flat magnetic field. Gravity anomalies in the part of the zone that was surveyed are also of considerable horizontal extent. The flat magnetic field southeast of $69^{\circ} \mathrm{W} ., 42^{\circ} \mathrm{N}$. coincides with the major gravity low that was attributed to a felsic pluton in a previous section. Magnetic anomalies along the margins of the gravity low may be caused by altered country rock or by smaller igneous bodies that are related to the felsic pluton. The broad arcuate magnetic low centered northeast of $70^{\circ} \mathrm{W} ., 41^{\circ} \mathrm{N}$. coincides with a zone of low-velocity $(5.0-\mathrm{kmps})$ basement that was mapped by Drake, Ewing, and Sutton (1959). The velocity is distinctly lower than that of the surrounding area (about $5.8 \mathrm{kmps}$ ), but it is not sufficiently distinctive to classify closely the probable rock type. The circular nature of the anomaly suggests a plu- tonic source, but the velocity is more typical of rocks of sedimentary origin.

Low-velocity strata in the area northwest of $70^{\circ}$ W., $41^{\circ} \mathrm{N}$. are nearly $1 \mathrm{~km}$ thick (Drake and others, 1959, fig. 35, Woods Hole section, sta. 3.2), which explains the broad gradients on the extensive magnetic high of this area and, possibly, the absence of magnetic anomalies in the area northwest of the high. The fairly intense amplitude and broad extent of the high indicate that the source is a mafic pluton. Small magnetic sources may be present in the area of flat magnetic field to the northwest, but large sources are apparently absent. The linear magnetic anomalies of moderate amplitude in the Cape Cod area suggest that igneous rocks are abundant in the subsurface. Only anomalies of low amplitude and small horizontal extent occur throughout the area north and northeast of Cape Cod, indicating that magnetic rocks are present only as minor constituents.

A narrow belt of low-gradient flat magnetic field forms the northwest boundary of the central magnetic zone. Apparent extensions of the belt on land to the northeast and west are underlain by felsic plutonic rocks and by stratified rocks in which volcanic rocks are a minor constituent. A broad gravity low in the south-trending part of the belt in the Gulf of Maine indicates the presence of a felsic pluton. A gravity high, however, having minor associated magnetic anomalies, is present farther southwest along the belt. In general, the flat magnetic field of the belt indicates the absence of major amounts of volcanic rock or of mafic plutonic rock. Under this interpretation, the presence of the gravity high is puzzling, but it may be caused by a deep source, as was suggested in the section on gravity (p.B10).

Linear magnetic highs of low to moderate amplitude are abundant in the gulf area just off the southern coast of Maine. The probable sources of these anomalies are folded belts of volcanic rocks.

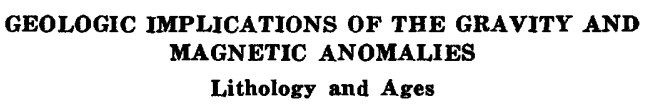

The results of the geophysical interpretation are summarized in figure 3 where distinctive lithologic units, deduced mainly from gravity anomalies, are superposed on the zones which correspond to regional contrasts in the magnetic field. It is estimated that all the indicated lithologic units are at least $1 \mathrm{~km}$ thick and that many are as thick as $3 \mathrm{~km}$ or more. Most of the units are probably igneous plutonic masses, but some may be composed of vol- 


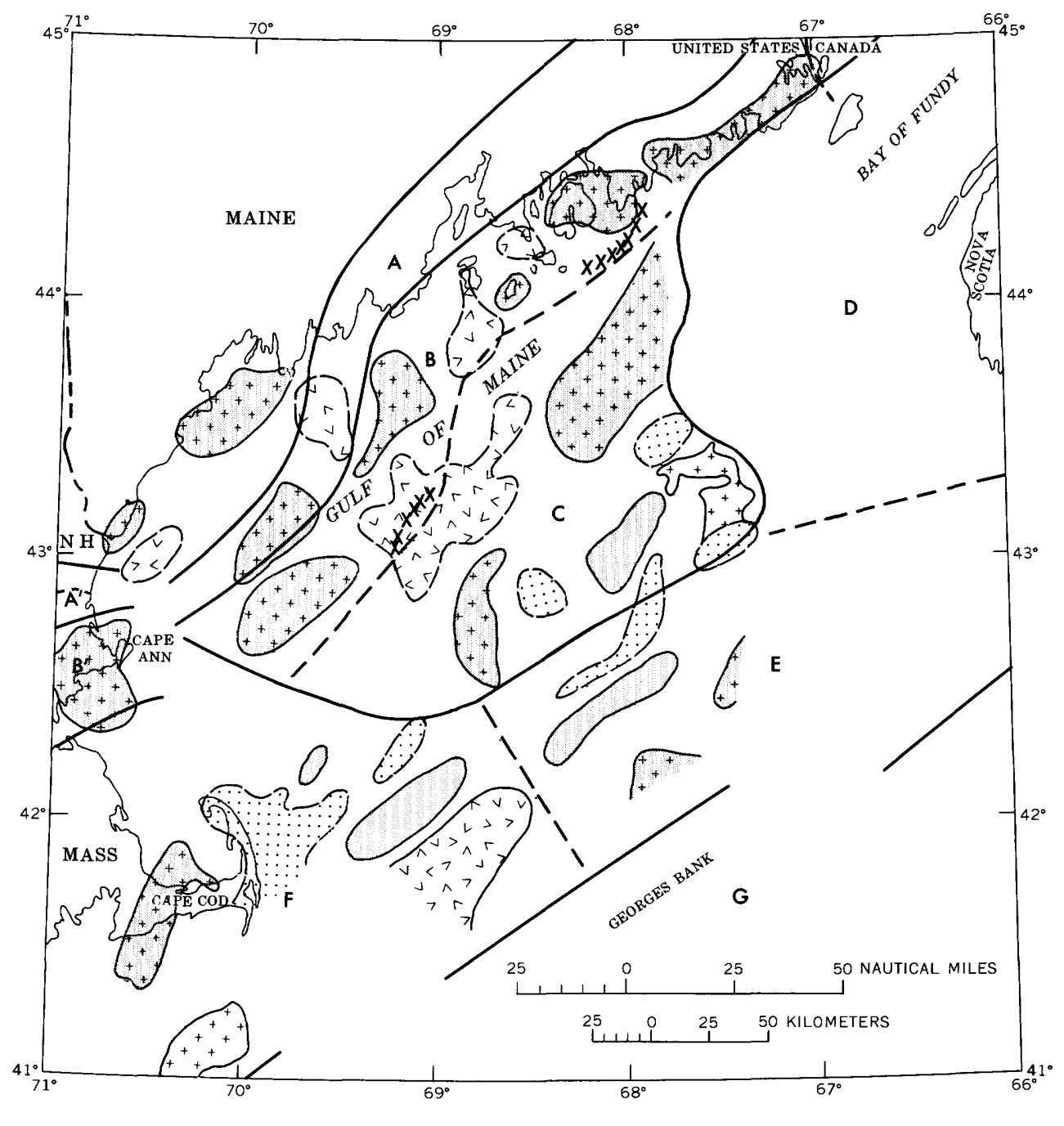

E X P L A N A T I ON
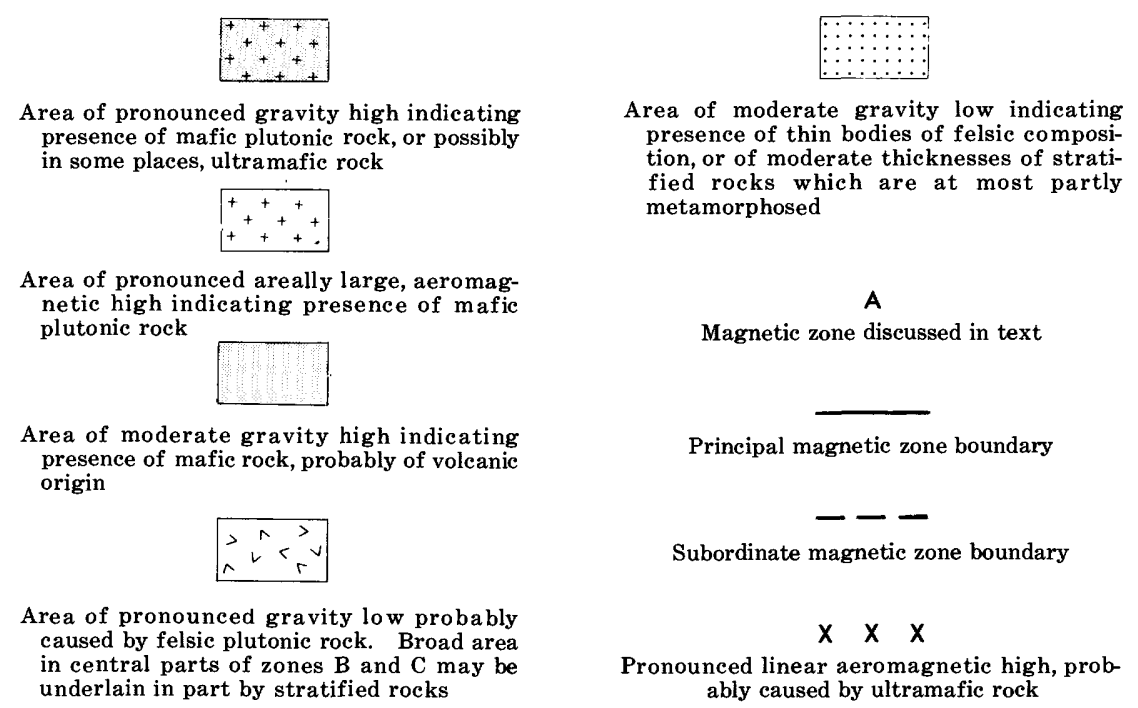

A

Magnetic zone discussed in text

Principal magnetic zone boundary

$$
\text { - - - }
$$

Subordinate magnetic zone boundary

$$
x \quad x
$$

Pronounced linear aeromagnetic high, probably caused by ultramafic rock

Figure 3.-Provisional lithologic map of the indurated bedrock of the Gulf of Maine, derived from gravity and aeromagnetic data. 
canic rocks or rocks of sedimentary origin. The uniform background gravity field shown in figure $3 \mathrm{im}$ plies that the host rock in the intervening areas has a grossly uniform density which is probably similar to that of average metamorphic rock. Some characteristics of the host rock in the individual zones are described below.

Note that figure 3 differs from a conventional geologic map in that the outlines of the lithologic units do not represent contacts at a single horizon. The interpreted sources of the anomalies are threedimensional bodies whose lateral boundaries can be located, for the most part, only within very broad limits. The outlines of the lithologic units may best be interpreted as very approximate estimates of the maximum lateral extents of the units. Part of the upper surface of most of the units, however, probably coincides with the metamorphic and igneous rock horizon mapped by Uchupi (1966). This conclusion is based on the observation that gravity anomaly sources in the surrounding land areas underlain by metamorphic terrane are almost always partly exposed. The exposures are most commonly found near the peaks of the anomalies.

The flat character of the magnetic field of zone A shows that it is underlain by magnetite-poor rocks. In Maine, the zone correlates with stratified rocks that are mapped as predominantly Cambrian and Ordovician in age and with felsic intrusive rocks that are Devonian in age. A possible extension of the zone in Massachusetts (zone $A^{\prime}$ ) is associated with rocks that may be Silurian in age (Billings, 1956), but the extension must be considered speculative because of the discontinuity in the vicinity of Cape Ann. In the Gulf of Maine, the zone is probably underlain by volcanic-poor stratified rocks of Cambrian and Ordovician age which are intruded in places by felsic plutons of Devonian age. The presence of mafic rock in the southwestern part of the zone in the gulf is, as stated earlier (p. B10), not consistent with the magnetic character of the zone, but the mafic rock may be deeply buried.

In contrast to zone $A$, the rocks of zone $B$ are magnetite rich, a characteristic which apparently reflects an extensive history of igneous activity. Correlations on land imply that the major plutonic components of the zone are Devonian in age and that the volcanic rocks are mostly Silurian in age (Gates, 1969). Mafic plutons predominate in the eastern Maine coastal area, but large felsic plutons are present in the extension of the zone in New Brunswick and, most probably, within the gulf. Some linear anomalies might be caused by elongate blocks of Precambrian rocks.

Magnetite-rich rocks are abundant in zone $\mathrm{C}$ but are more widely separated than those in zone $B$. The general appearance of parts of the magnetic field of this zone resembles that over the region in New Brunswick underlain by rocks of Precambrian age. Because of this resemblance, the bedrock is tentatively identified as probably Precambrian in age, at least in part. Rocks of Carboniferous age may be present within zones $B$ and $C$, in the areas which have a flat magnetic field.

Zone $\mathrm{D}$ encompasses almost all the area that Uchupi (1966) showed as being underlain by stratified rocks of Triassic age. As pointed out earlier, (p. B12), the magnetic aspects of this zone are very similar to those of the Triassic basin in southeastern Pennsylvania (Bromery and Griscom, 1967). As in Pennsylvania, some of the flat magnetic field peripheral to the indicated area of strata of Triassic age may be underlain by stratified rocks of Carboniferous or older age. Furthermore, rocks of Triassic age may possibly extend beyond the limits of zone $\mathrm{D}$, inasmuch as some of the anomalies of the northern part of zone $\mathrm{C}$ are similar to those over extensive exposures of diabase in the Pennsylvania area. The circular magnetic anomaly discovered by Malloy and Harbison (1966), for example, could be caused by an arcuate emplacement of diabase.

Zones $\mathbf{E}$ and $\mathbf{F}$ are characterized by widelyspaced anomalies of moderate amplitude, a condition which permits a considerable range of possible correlations. The magnetic character of zone $\mathrm{E}$ is somewhat like that of the stratified rocks of Ordovician age in Nova Scotia and may indicate an extension of these rocks to this part of the gulf. The widely spaced broad anomalies that make up much of zone $\mathbf{F}$ do not clearly resemble the magnetic field over any of the nearby land areas.

Structure

The dominant gravity and magnetic trends of the Gulf of Maine indicate that the main structural grain is northeast, in accord with that of the Appalachians as a whole. Direct gravity and magnetic evidence of discrete structures underlying the gulf is generally precluded by the wide spacing of the measurements. Discontinuities in the patterns of the magnetic field in some areas, however, suggest abrupt changes in gross bedrock units which can best be explained by major faults. The most obvious discontinuity is between the linear magnetic zones $A$ and $B$ in the gulf and their extensions $A^{\prime}$ and $B^{\prime}$ 
in southern New England. If these zones were in fact once continuous, then a major fault offsets them in the vicinity of Cape Ann. A plausible mechanism for the offset is the great imbricate thrust fault described by Bell (1967) which strikes into the gulf north of Cape Ann. A conclusive demonstration of this relationship, however, would require both land and sea surveys in considerably more detail.

Near the east margin of the gulf, sharp changes in the character and trends of the magnetic field suggest the presence of a major north-trending structural discontinuity. On the north, the transition from a very flat magnetic field over the Bay of Fundy to an anomalous field over and southwest of Grand Manan Island indicates a fairly abrupt change from a broad basin uniformly underlain by a thick sequence of nonmagnetic stratified rocks to a region where broad blocks of magnetic rock (Precambrian?) are near or at the sea bottom. To the south, linear magnetic anomalies that strike southwest on the Nova Scotian peninsula bear sharply south in the western and southern coastal areas. Apparent extensions of these linear anomalies in the gulf and broad anomalies in the western part of zone $\mathrm{D}$ also have a southward alinement. Just north of $43^{\circ} \mathrm{N}$., the southward trends terminate and are replaced to the south by southwestward trends. Taken together these changes in the magnetic field suggest a structural break between the Bay of Fundy-Nova Scotia region and the eastern Gulf of Maine. Realinement of flat parts of the magnetic field indicates that there may be a northward component of movement with left-lateral sense and as much as $50 \mathrm{~km}$ of displacement.

Although the present gravity and magnetic data provide no direct evidence of the Fundian fault system of Johnson (1925) or of a gulfward extension of the rift system of Belt (1968), the interpretation of these data is compatible with the location of structures like these within the gulf. Gates (1969) interpreted the setting and structural style of volcanic rocks in eastern Maine as evidence of a crustal zone of weakness along which major horizontal displacements took place in late Paleozoic and early Mesozoic time. Presumably, magnetic zone $B$ is a manifestation, at least in part, of an extension of the volcanic rocks within the gulf. A linear magnetic high, which extends from the northeast end of the volcanic belt described by Gates (1969) to the Gulf of St. Lawrence (Bhattacharyya and Raychaudhuri, 1967), is underlain by structural highs in the bedrock geology. Thus a linear magnetic high, appar- ently marking the location of a major crustal fault, extends from the Gulf of St. Lawrence to the southern New England coast. This interpretation supports the presence in the Gulf region of a northeast-trending fault of continental dimensions as proposed by Wilson (1962) and by Webb (1968). The presence of rift structures, like those described by Belt (1968), is also compatible with the interpretation of some of the gravity lows and with some of the areas of very flat magnetic field within the central part of the gulf.

\section{CRUSTAL STRUCTURE OF THE GULF OF MAINE}

The uniformly high Bouguer gravity field, the abundance of mafic rock units, and the comparatively high velocity of shallow bedrock (Drake and others, 1954) are evidence that the crust underlying the Gulf of Maine differs substantially from that of the surrounding areas. Some gross properties of that crust and their influence on the formation of the gulf are indicated by several aspects of the gravity field.

The average free-air gravity field over the gulf (Yellin, 1968) and over Maine is slightly positive, indicating that the region is near isostatic equilibrium; that is, the differential surface loads caused by regional variations in the topography of the land and sea floor are balanced by subsurface masses of offsetting density contrast. Accordingly, the mass load represented by the rise in bedrock surface from the gulf to the interior of Maine must be balanced by subsurface masses of negative density contrast. As shown by analyses of the Bouguer gravity field, these balancing masses are located, at least in part, in the uppermost crust. Part of the isostatic equilibrium may be achieved by changes in crustal thickness, but changes in crustal thickness are not required to explain the regional variations in the Bouguer field.

The close correspondence between the shore of the gulf and the landward edge of the high gravity level (pl. 1) suggests that the depression of the bedrock surface and the source of the gravity level are causally related. More specifically, isostatic theory implies that the shallow high-density source of the gravity level causes an effective negative buoyancy and thereby restrains the bedrock surface below sea level. The uniformity of the high gravity level also suggests that the crust beneath the gulf may act as a single block or plate in response to whatever surface or body forces are present. A similar block geometry was described for the crust un- 
derlying Maine (Kane and Bromery, 1968) and would appear to apply equally well to the major peninsula that makes up southwestern Nova Scotia, where the crustal block is presumably buoyed positively by the relatively low-density pluton that underlies much of the peninsula (Garland, 1953). The major inference of this concept of crustal blocks is that the relative mass of extensive bodies of nearsurface rocks may provide at least a partial control on the vertical position and attitude of the crustal block in which they occur.

Figure 4 is a crustal model that accounts for both the horizontal gradients and the amplitudes of the regional Bouguer gravity field by changes in the density and thickness of stratified rocks of Paleozoic age overlying a high-density basement of Precambrian age. The model is based on changes in level of the smoothed regional Bouguer gravity field, maximum depths to the density contrasts giving rise to these changes, an evaluation of the density of metamorphosed rocks of pre-Devonian age (Kane and Bromery, 1968), and recent specific gravity measurements on samples of stratified rocks of Devonian age from northwestern Maine. The vertical contacts of the crustal masses are arbitrary, except to the extent that the maximum-depth calculations are based on mass boundaries which have this attitude. If the boundaries sloped appreciably less than $90^{\circ}$, then the maximum depths would be correspondingly less. The critical constraints imposed by the gravity data are as follows: (1) Maximum depths to the shallowest density contrasts at junctures $\mathrm{A}, \mathrm{B}$, and $\mathrm{C}$ range from 5 to $8 \mathrm{~km}$, and (2) the density of the medium on the southeast side of the juncture is always higher; that is, the gravity field is always higher to the southeast. The incorporation of the geologic and density data leads to a model in which these lateral contrasts in density are caused by vertical displacements of crustal blocks (increasing uplift to the southeast); in the blocks, density increases with depth, and subsequent erosion has resulted in the present lateral density contrasts. The geologic aspects of the model are speculative, but they fit well with other information such as the high compressional-wave velocity of the "subbasement" beneath the gulf (Drake and others, 1954). The physical aspects (density, depth, volume) of the model are more certain, however, and any model based on these data must have a density distribution that is similar to that shown here.

The identification of shallow intracrustal sources for variations in the regional Bouguer gravity field
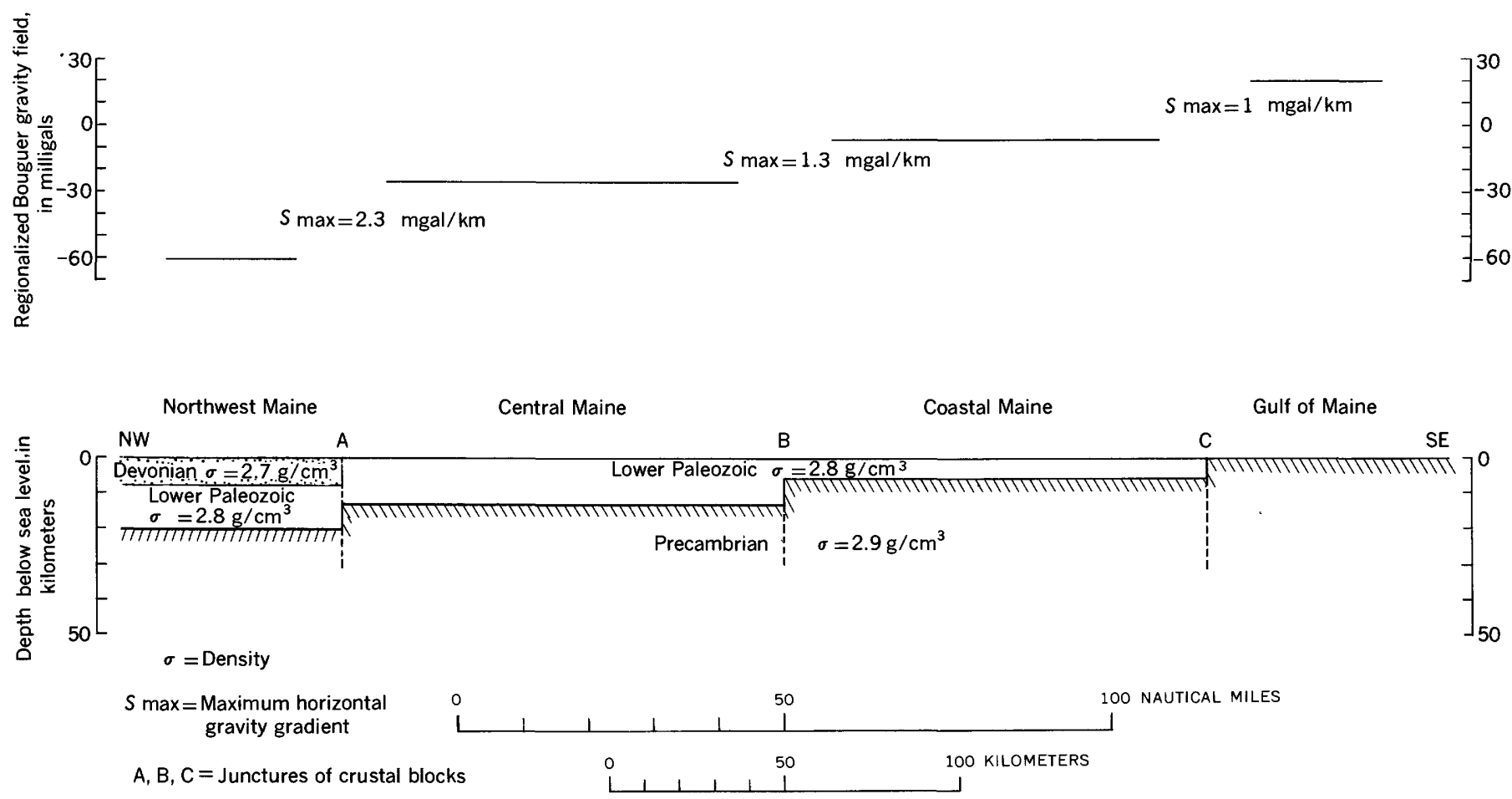

FIGURE 4.--Regionalized Bouguer gravity field, maximum horizontal gravity gradients, and hypothetical density distribution of the Gulf of Maine-Maine region based on the assumption that the gravity-field variation is caused by changes in thickness of the Paleozoic stratified rocks. 
supports the finding of Pakiser and Steinhart (1964) that the simple empirical relation between regional Bouguer gravity and crustal thickness is not generally valid. Weaver (1967) reported a similar conclusion for Newfoundland where a high regional Bouguer gravity level correlates with a thick (42-km) high-velocity crust and a high-velocity mantle, and a low gravity level correlates with a thin $(31-\mathrm{km})$ low-velocity crust and a low-velocity mantle. The seismic-velocity model of the crust in the Gulf of Maine (Steinhart and others, 1962) is generally intermediate to these two models, although the Bouguer gravity level is significantly higher than the high gravity level of the Newfoundland region. These results suggest that the present data are insufficient for speculation about the overall nature of the deeper crust in the gulf region.

\section{SUMMARY}

The geologic results of this investigation of the Gulf of Maine represent a provisional description and distribution of gross units of indurated bedrock and an outline of some of the major structures. The principal conclusions are that (1) the indurated bedrock contains abundant mafic rocks and is probably mainly of early Paleozoic or Precambrian age and (2) major faults are along at least some margins of the gulf. The crust that underlies the gulf appears to be distinctly different from that of the surrounding areas, but it does not clearly resemble any of the known conventional models of the crust. Two important properties of the crust are that high-density rock $\left(2.9 \mathrm{~g} / \mathrm{cm}^{3}\right)$ seems to occur at very shallow crustal depths and that isostatic equilibrium is achieved, at least partly, by major rock masses at shallow crustal depths.

Gravity surveys in the near-coast areas (represented by dashed contours on pl. 1) and over the surrounding continental shelf are needed to extend and possibly modify the conclusions presented here. Detailed magnetic and continuous seismic profiling of the type done by Malloy and Harbison (1966) would be especially useful in providing details about the bedrock. These surveys would substantially fill the hiatus between this study and that of Uchupi (1966) and would provide more detailed information on the gross features described herein. More seismic measurements of velocities of the bedrock are needed, particularly in areas where gravity anomalies indicate the presence of either felsic plutonic rock or porous stratified rock.

The findings of this study bearing on crustal structure suggest that gravity and magnetic sur- veys can provide useful guides to the location of deep-probing seismic-refraction profiles. Interpretation of this type of seismic data would be more straightforward if the profiles were not located so as to cross the boundaries between contrasting crustal blocks.

\section{REFERENCES CITED}

Allingham, J. W., 1961, Aeromagnetic interpretation of zoned intrusions in northern Maine: U.S. Geol. Survey Prof. Paper 424-D, p. D265-D266.

Bancroft, A. M., 1960, Gravity anomalies over a buried step: Jour. Geophys. Research, v. 65, p. 1630-1631.

Bell, K. G., 1967, Faults in eastern Massachusetts [abs.]: Geol. Soc. America, Northeastern Sec., 2d Ann. Mtg., Boston, Mass., 1967, Program, p. 14.

Belt, E. S., 1968, Post-Acadian rifts and related facies, eastern Canada, in Zen, E-an, White, W. S., Hadley, J. B., and Thompson, J. B., Jr., eds., Studies of Appalachian geology-northern and maritime: New York, Intersci. Publishers, p. 95-113.

Bhattacharyya, B. K., and Raychaudhuri, B., 1967, Aeromagnetic and geological interpretation of a section of the Appalachian belt in Canada: Canadian Jour. Earth Sci., v. 4, p. 1015-1037.

Billings, M. P., compiler, 1955, Geologic map of New Hampshire: U.S. Geol. Survey, scale 1:250,000.

Billings, M. P., 1956, Bedrock geology, Part 2 of The geology of New Hampshire: Concord, N.H., New Hampshire State Planning and Devel. Comm., 203 p.

Bott, M. H. P., 1962, A simple criterion for interpreting negative gravity anomalies: Geophysics, v. 27, p. 376-381.

Bott, M. H. P., and Smith, R. A., 1958, The estimation of the limiting depth of gravitating bodies: Geophys. Prosp. [Netherlands], v. 6, p. 1-10.

Boucot, A. J., 1968, Silurian and Devonian of the Northern Appalachians, in Zen, E-an, White, W. S., Hadley, J. B., and Thompson, J. B., Jr., eds., Studies of Appalachian geology-northern and maritime: New York, Intersci. Publishers, p. 83-94.

Boucot, A. J., Griscom, Andrew, and Allingham, J. W., 1964, Geologic and aeromagnetic map of northern Maine: U.S. Geol. Survey Geophys. Inv. Map GP-312, scale $1: 250,000$.

Bromery, R. W., 1967, Simple Bouguer gravity map of Massachusetts: U.S. Geol. Survey Geophys. Inv. Map GP-612, scale 1:250,000.

Bromery, R. W., and Griscom, Andrew, 1967, Aeromagnetic and generalized geologic map of southeastern Pennsylvania: U.S. Geol. Survey Geophys. Inv. Map GP-577, scale $1: 125,000$.

Cady, W. M., 1960, Stratigraphic and geotectonic relationships in northern Vermont and southern Quebec: Geol. Soc. America Bull., v. 56, p. 515-587.

Cady, W. M., 1967, Geosynclinal setting of the Appalachian Mountains in southeastern Quebec and northwestern New England: Royal Soc. Canada Spec. Pub. 10, p. $57-68$.

Canada Geological Survey, 1968, Aeromagnetic series and ship magnetometer survey series: Canada Geol. Survey, Index to Map Sheets, sheet 1. 
Chapman, C. A., 1962, Bays of Maine igneous complex: Geol. Soc. America Bull., v. 73, p. 883-888.

Dixon, H. R., and Lundgren, L. W., Jr., 1968, Structure of eastern Connecticut, in Zen, E-an, White, W. S., Hadley, J. B., and Thompson, J. B., Jr., eds., Studies of Appalachian geology-northern and maritime: New York, Intersci. Publishers, p. 219-229.

Doll, C. G., Cady, W. M., Thompson, J. B., Jr., and Billings, M. P., compilers and eds., 1961, Centennial geologic map of Vermont: Montpelier, Vt., Vermont Geol. Survey, scale $1: 250,000$.

Drake, C. L., Ewing, W. M., and Sutton, G. H., 1959, Continental margins and geosynclines-the east coast of North America north of Cape Hatteras, in Ahrens, L. H., Press, Frank, Rankama, Kalervo, and Runcorn, S. K., eds., Physics and chemistry of the earth, Volume 3 : London, Pergamon Press, p. 110-198.

Drake, C. L., Heirtzler, J. R., and Hirshman, Julius, 1963, Magnetic anomalies off eastern North America: Jour. Geophys. Research, v. 68, p. 5259-5275.

Drake, C. L., Worzel, J. L., and Beckmann, W. C., 1954, Geophysical investigations in the emerged and submerged Atlantic Coastal Plain-Part 9, Gulf of Maine: Geol. Soc. America Bull., v. 65, p. 957-970.

Emery, K. O., and Uchupi, Elazar, 1965, Structure of Georges Bank: Marine Geology, v. 3, p. 349-358.

Emery, K. O., Uchupi, Elazar, Phillips, J. D., Bowin, C. O., Bunce, E. T., and Knotts, S. T., 1970, Continental rise off eastern North America: Am. Assoc. Petroleum Geologists Bull., v. 54, p. 44-108.

Garland, G. D., 1953, Gravity measurements in the Maritime Provinces: Ottawa, Dominion Observatory Pub., v. 16, p. 185-275.

Gates, Olcott, 1969, Lower Silurian-Lower Devonian volcanic rocks of New England coast and southern New Brunswick, in Kay, Marshall, ed., North Atlantic-geology and continental drift: Am. Assoc. Petroleum Geologists Mem. 12, p. 484-503.

Goldsmith, Richard, 1964, Geologic map of New England: U.S. Geol. Survey open-file map, scale $1: 1,000,000$.

Griscom, Andrew, and Bromery, R. W., 1968, Geologic interpretation of aeromagnetic data for New England, in Zen, E-an, White, W. S., Hadley, J. B., and Thompson, J. B., Jr., eds., Studies of Appalachian geology-northern and maritime: New York, Intersci. Publishers, p. 425-436.

Hansen, W. R., 1956, Geology and mineral resources of the Hudson and Maynard quadrangles, Massachusetts: U.S. Geol. Survey Bull. 1038, 104 p.

Hoskins, Hartley, and Knott, S. T., 1961, Geophysical investigation of Cape Cod Bay, Massachusetts, using the continuous seismic profiler: Jour. Geology, v. 69, p. $330-340$.

Hussey, A. M., 1968, Stratigraphy and structure of southwestern Maine, in Zen, E-an, White, W. S., Hadley, J. B., and Thompson, J. B., Jr., eds., Studies of Appalachian geology—northern and maritime: New York, Intersci. Publishers, p. 291-301.

Hussey, A. M., Chapman, C. A., Doyle, R. G., Osberg, P. H., Pavlides, Louis, and Warner, Jeffrey, compilers, 1967, Preliminary geologic map of Maine: Augusta, Maine, Maine Geol. Survey, scale 1:500,000.

Johnson, D. W., 1925, The New England-Acadian shoreline: New York, John Wiley \& Sons, 608 p.
Joyner, W. B., 1963, Gravity in north-central New England: Geol. Soc. America Bull., v. 74, p. 831-858.

Kane, M. F., 1961, Structure of plutons from gravity measurements: U.S. Geol. Survey Prof. Paper 424-C, p. C258-C259.

1968, Metamorphic and igneous events reflected in the gravity field over the New England Appalachians [abs.]: Geol. Soc. America Spec. Paper 121, p. 152-153. 1970, Geophysical study of the tectonics and crustal structure of the Gulf of Maine: St. Louis, Mo., St. Louis Univ., Ph.D. dissertation, $106 \mathrm{p}$.

Kane, M. F., and Bromery, R. W., 1966, Simple Bouguer gravity map of Maine: U.S. Geol. Survey Geophys. Inv. Map GP-580, scale 1:500,000.

- 1968, Gravity anomalies in Maine, in Zen, E-an, White, W. S., Hadley, J. B., and Thompson, J. B., Jr., eds., Studies of Appalachian geology-northern and maritime: New York, Intersci. Publishers, p. 415-423.

Keller, Fred, Jr., Meuschke, J. L., and Alldredge, L. R., 1954, Aeromagnetic surveys in the Aleutian, Marshall, and Bermuda Islands: Am. Geophys. Union Trans., v. 35, p. 558-572.

King, P. B., compiler, 1969, Tectonic map of North America: U.S. Geol. Survey, 2 sheets, scale 1:5,000,000.

Malloy, R. J., and Harbison, R. N., 1966, Marine geology of the northeastern Gulf of Maine: U.S. Coast and Geod. Survey Tech. Bull. 28, 15 p.

Osberg, P. H., Moench, R. H., and Warner, Jeffrey, 1968, Stratigraphy of the Merrimack synclinorium in westcentral Maine, in Zen, E-an, White, W. S., Hadley, J. B., and Thompson, J. B., Jr., eds., Studies of Appalachian geology_northern and maritime: New York, Intersci. Publishers, p. 241-253.

Pakiser, L. C., and Steinhart, J. S., 1964, Explosion seismology in the western hemisphere, in Odishaw, Hugh, ed., Research in geophysics-Volume 2, Solid earth and interface phenomena: Cambridge, Massachusetts Inst. Technology Press, p. 123-147.

Pavlides, Louis, 1965, Geology of the Bridgewater quadrangle, Aroostook County, Maine: U.S. Geol. Survey Bull. $1206,72 \mathrm{p}$.

Perkins, E. H., and Smith, E. S. C., 1925, A geological section from the Kennebec River to Penobscot Bay: Am. Jour. Sci., 5th ser., v. 9, p. 204-228.

Quinn, A. W., and Moore, G. E., Jr., 1968, Sedimentation, tectonism, and plutonism of the Narragansett Basin region, in Zen, E-an, White, W. S., Hadley, J. B., and Thompson, J. B., Jr., eds., Studies of Appalachian geology-northern and maritime: New York, Intersci. Publishers, p. 269-279.

Rankin, R. W., 1968, Volcanism related to tectonism in the Piscataquis volcanic belt, an island arc of Early Devonian age in north-central Maine, in Zen, E-an, White, W. S., Hadley, J. B., and Thompson, J. B., Jr., eds., Studies of Appalachian geology-northern and maritime: New York, Intersci. Publishers, p. 241-253.

Reed, J. C., Jr., Owens, J. P., and Stockard, H. P., 1967, Interpretation of basement rocks beneath the Atlantic Coastal Plain from reconnaissance aeromagnetic data [abs.]: Geol. Soc. America Spec. Paper 115, p. 182-183. Schlee, John, and Pratt, R. M., 1970, Atlantic Continental Shelf and Slope of the United States-Gravels of the northeastern part: U.S. Geol. Survey Prof. Paper $529-\mathrm{H}, 39 \mathrm{p}$. 
B22

GEOPHYSICAL FIELD INVESTIGATIONS

Steinhart, J. S., Green, R., Asada, T., Rodriguez, B. A., Aldrich, L. T., and Tuve, M. A., 1962, Seismic studies: Carnegie Inst. Washington Year Book 61, 1961-62, p. 221-234.

Taylor, P. T., Zietz, Isidore, and Dennis, L. S., 1968, Geologic implications of aeromagnetic data for the eastern continental margin of the United States: Jour. Geophys. Research, v. 33, p. 755-780.

Toulmin, Priestly, Bd, 1957, Notes on a peralkaline granite from Cashes Ledge, Gulf of Maine: Am. Mineralogist, v. 42 , p. 912-915.

Uchupi, Elazar, 1965, Maps showing relation of land and submarine topography, Nova Scotia to Florida: U.S. Geol. Survey Misc. Geol. Inv. Map I-451, scale $1: 1,000,000$.

- 1966, Structural framework of the Gulf of Maine: Jour. Geophys. Research, v. 71, p. 3013-3028.

Vacquier, Victor, Steenland, N. C., Henderson, R. G., and Zietz, Isidore, 1951, Interpretation of aeromagnetic maps: Geol. Soc. America Mem. 47, 151 p.

Weaver, D. F., 1967, A geological interpretation of the Bouguer anomaly field of Newfoundland: Ottawa, Dominion Observatory Pub., v. 35, p. 223-251.
Webb, G. W., 1968, Palinspastic restoration suggesting late Paleozoic North Atlantic rifting: Science, v. 159, p. 875-878.

Wilson, J. T., 1962, Cabot fault, an Appalachian equivalent of the San Andreas and Great Glen faults and some mmplications for continental displacement: Nature, v. 195, p. 135-138.

White, W. S., compiler, 1968, Generalized geologic map of the northern Appalachian region, in Zen, Elan, White, W. S., Hadley, J. B., and Thompson, J. B., Jr., eds., Studies of Appalachian geology -northern and maritime: New York. Intersci. Publishers, scale 1:2,500,000.

Worzel J. L., and Shurbet, G. L., 1955, Gravity anomalies at continental margins: Natl. Aced. Sci. Proc., v. 41, p. $458-469$.

Yellin, M. J., 1968, Gravity survey of the Continental Shelf, seabottom and seasurface survey, Gulf of Maine: U.S. Coast and Geod. Survey Operational Data Rept. C and GSDR-2, 12 p.

Zen, Elan, 1968, Introduction, in Zen, E-an, White, W. S., Hadley, J. B., and Thompson, J. B., Jr., eds., Studies of Appalachian geology-northern and maritime: New York, Intersci. Publishers, p. 1-5.

U.S. GOVERNMENT PRINTING OFFICE : 1972 O - 454-534 